\title{
1. Private pensions versus social inclusion? Citizens at risk and the new pensions orthodoxy
}

\section{Paul Bridgen and Traute Meyer}

Societal ageing is one of the major challenges facing social policymakers today. For many European countries it is predicted that in the near future there will be more pensioners than people in employment. During the 1990s a consensus amongst Western social policymakers has emerged that welfare states need more private pension provision in order to master this trend (Haverland 2001, pp. 310-11; World Bank 1994). The policy shift that has followed is justified on the basis of concerns about the effect of demographic changes on the sustainability of existing pensions systems and arguments about economic efficiency. A multi-pillar system, many believe (European Commission 2003; World Bank 1994), is better able to cope with the problems created by population ageing, with pre-funded pensions also regarded as superior to pay-as-you-go pensions in terms of rates of return. The basis for this consensus, which some call the 'new pensions orthodoxy' (Müller 1999), has not gone unchallenged (Augusztinovics 2002; Barr 2000) but, nevertheless, a shift away from public provision and an increase in private forms has been the predominant development in the pensions systems of most, if not all, industrialized countries (Bonoli et al. 2000; OECD 2005a; Pedersen 2004; Zaidi et al. 2006).

What do these trends mean for the adequacy of citizens' pensions? Are we about to see pensioner poverty rise after many years in which it has fallen in most industrialized welfare states (Casey and Yamada 2003)? Most European governments believe we are not; they are confident that steps taken towards privatizing national pension regimes have not compromised their aim to maintain social inclusion. This view is bolstered by the European Council and Commission who expressed confidence that public-private regimes are capable of protecting the great majority of citizens from social exclusion:

Pension systems, through public earnings-related schemes (first pillar), private occupational schemes (second pillar) and individual retirement provision (third 
pillar), provide good opportunities for most Europeans to maintain their living standards after retirement - as a result, and in combination with other taxbenefit policies for pensioners, older people, in most Member States, generally achieved a fair, and in some Member States even relatively high, living standard. (European Commission 2003, p. 6; see also European Council 2006)

This position, however entrenched it may be at the present time, is not based on a systematic theoretical and empirical appraisal of the potential of private provision. Despite the almost universal shift towards non-public forms of pensions, and even though European societies seem to have reached a 'point of no return' as far as the likelihood of governmental support for stronger public sectors is concerned, there remain important gaps in our knowledge about the implications of recent policy developments. The view among policymakers and in academia that pension regimes must have private elements to make them financially sustainable is very strong, but it is not clear how successful the joint performance of the different pillars of current regimes actually is with regard to social inclusion, particularly for the protection of citizens without lifelong, full-time employment biographies. It follows from this that there is also a lack of knowledge about what type of 'public-private mixes' best ensure not only financial sustainability but also a retirement free from social exclusion for citizens at risk. It is the aim of this book to address these knowledge gaps.

In the academic realm empirical studies are rare on the distributive implications of the increased use of non-state provision in European pension systems and thus the potential of occupational pensions and private savings to supplement the first pillar (OECD 2005b, p. 9). This is not to say that the field is untouched. Especially in the three countries analysed here with a long legacy of public and private pension provision - the Netherlands, Switzerland and the United Kingdom - knowledge is well established about the general level of public and private sector performance. Research on the Netherlands and Switzerland has demonstrated the general inclusiveness of the public pillar in conjunction with occupational pensions (Chapters 3 and 4), while in Britain academic analyses of pensions have highlighted the high poverty risks generated by the insufficient level of the public pension and the selective nature of occupational schemes (Chapter 2). However given the role non-state provision plays in these three 'veteran' countries, there has been less interest than one might expect in the heterogeneity of non-state provision. Questions that ask what types of arrangements are more or less successful, or which sectors of the economy do better than others for citizens at risk and why, still remain to be answered. Moreover little work has so far been done on the distributive consequences of recent retrenchments in all three countries (Bridgen and Meyer 2005; OFS 2004; van Riel et al. 2003). For obvious reasons, we know even less about private sector performance in the 
three other countries of our study that have only recently undergone system changes: Germany, Italy and Poland.

Given this deficit regarding individual countries it is not surprising that comparative assessments are even rarer (OECD 2005b; Social Protection Committee 2006; Zaidi et al. 2006). Few cross-national studies analyse pension regimes in terms of their contribution to social inclusion. Instead a substantial proportion of recently published comparative research on pensions or welfare regimes has concentrated on policy transformation and pension politics with much less attention paid to the distributive consequences of these changes (Immergut et al. 2007; Bonoli and Shinkawa 2005; Clark and Whiteside 2003; Rein and Schmähl 2004; Shalev 1996). Where analyses include the impact of such policies on citizens they have tended not to differentiate between private and public pension elements (Johnson and Rake 1998), and are generally based on the use of macro-level data, such as labour market or income figures (Disney and Johnson 2001). The problem with the latter is that such data give no clear sense of the connection between policies and outcomes because they are a product not just of the policy regime in a country but also the economic and social context. Micro-level data are thus essential in the analysis of present policy because they allow a firm connection to be made between the regime and the pension outcomes of individual biographies, and on this basis make it possible to assess the comparative performance of different pension regimes for identical individuals (Johnson and Rake 1998). On this basis one can demonstrate which of the national regimes works best for various types of individual. So far comparative research that utilizes such data to study processes of social exclusion has not generally considered the role of pensions (Aposori and Millar 2005; Barnes et al. 2004; Berthoud and Iacovou 2004; Goodin et al. 1999).

However there are a few pioneering comparative evaluations of the outcomes of public-private pensions regimes based on this type of approach (OECD 2005b; Social Protection Committee 2006). Yet in terms of evaluating the risks of social exclusion they have two important limitations. Firstly they are based on overly simplified biographies of individuals. In particular, the life events encountered by many contemporary citizens and the potential social risks they constitute remain unexplored. Secondly the studies simulate the income of individuals only. The potentially considerable impacts of marriage and divorce on social inclusion after retirement, through divorce payments, derived rights through marriage and through the pooling of resources in one household, are not considered at all.

Put in broad terms, therefore, this book will explore to what extent the widespread confidence that multi-pillar arrangements pose no major problems for levels of social exclusion is justified. We start from the premise 
that if this confidence were warranted, current pension regimes - public, collective, employer-related and personal - should be able to offer protection not just to citizens with incomes on or above the average, but also to those with working lives characterized by the complexity of typical contemporary social risks. Taking this perspective we examine the performance of six current national pension regimes in Europe for these 'risk biographies', individuals and couples. More specifically, the six country chapters that follow will concentrate on three main questions:

- What is the nature of the public-private mix in each pension regime?

- What pension levels can hypothetical 'risk biographies' on incomes below the average but above the poverty line expect under current conditions, ${ }^{1}$ and what is the contribution of the private and the public sector to their pension outcomes?

- How do the policymakers responsible for reform aim to address the main shortcomings of their regimes for 'risk biographies', given that generally a strengthening of the public sector is not considered a viable option?

\section{CONCEPTUAL AND METHODOLOGICAL ISSUES}

The research on which this book is based has sought to avoid the main limitations in existing work on this area. Firstly public and private types of insurance were systematically included in the assessment of each of the country regimes in relation to social inclusion. Secondly in establishing the outcomes of these regimes, the research builds on a more realistic range of 'biographies', whose life courses reflect the variety of social risks experienced by individuals in post-industrial societies. This approach raised a number of important conceptual and methodological issues that need to be addressed at this stage.

\section{Public and Private Pensions}

Any assessment of the respective role of different types of pension provision in preventing social exclusion in retirement has first to address the debate about the meaning of some basic concepts, such as 'private pensions' and 'privatization'. Despite their prominence in political and academic debates, these remain shrouded by a good deal of ambiguity with important implications for their operationalization in the analysis of social policy change. For many economists and the World Bank, 'private' equals 'pre-funded' systems, and they see a superiority of this form over pay-as-you-go programmes in 
terms of financial sustainability. In the broader academic debate, a dichotomous public-private typology has often been used to categorize pensions, ${ }^{2}$ with debate hinging on where to draw the line between public and private (for example Behrendt 2000, p. 26; Esping-Andersen 1990, p. 91; Pedersen 2004). On the basis of this dichotomizing approach 'privatization' involves a simple shift from the public side to the private side.

While this approach has its merits, there is a growing recognition that restrictive sectoral definitions of pension type unnecessarily limit or simplify the meaning of 'privatization' and hinder our understanding of the distributive consequences of pension regime design (Drakeford 2000; Hyde et al. 2003, pp. 189-90; Rein and Wadensjö 1997; Shalev 1996). In all countries studied in this book, pension entitlements are the outcome of complex interaction regarding regulation, funding and administration, and therefore the arrangements on which they are based defy a clear-cut public-private labelling (Leisering 2003). It is misleading to speak for example of the success of the 'private' Swiss or Dutch second pillar in terms of social inclusion, if the substantial role the state as regulator played for such success is neglected. For this reason, this book heeds the call for a 'more sophisticated approach' (Burchardt 1997, p. 2; Hyde et al. 2003; van Gunsteren and Rein 1985, p. 230) to the categorization of public and private welfare provision; one that recognizes the existence of a wide variety of instruments that involve different forms of public-private interaction. Thus rather than categorizing pension regimes as either 'public' or 'private', we suggest there is a continuum of regimes all of which mix in various ways pensions with public and private aspects (see below).

This also means that we understand 'privatization' not merely as a shift from 'public' to 'private' or unfunded to funded schemes; rather privatization is any process whereby the state's role in pension provision and regulation is reduced and the responsibility of a variety of other societal actors - employers, insurers, trade unions and individual citizens - for retirement provision is either passively or actively increased (Bonoli et al. 2000). On this basis our aim is to determine not whether 'public' regimes 'work' better than 'private' regimes but rather which combinations of public and private engagement in pensions are most consistent with social inclusion.

\section{Constructing 'Risk Biographies'}

To help us make this assessment we microsimulated the pension outcomes of a range of 'risk biographies'. We suggested above that a problem with existing assessments of pension regime performance on this basis was the use of unrealistically simple, standardized biographies for establishing outcomes. Thus in its study, the OECD only examines the 'pension entitlements of a 
worker who enters the system today and retires after a full career' (OECD 2005b, p. 40). Similarly the European Commission's Social Protection Committee selects for calculation three full-time, lifelong workers and one variant of a broken career, defined as a person with an employment biography of 30 full-time years, split in two phases by ten years outside the labour market (Social Protection Committee 2006, pp. 7-10). ${ }^{3}$ While the latter approach incorporates to some extent care responsibility as a risk, the fulltime, lifelong worker remains the centre of attention for both studies. Thus they do not, or to a limited extent only, consider the complex rules which determine pension rights across all pillars in case of life events such as care responsibilities, divorce, disability, unemployment, training, early retirement, change of employer or migration. In contrast the hypothetical individuals presented in this book are modelled according to the complexity of real people's lives. This implies that their wages oscillate throughout their lives, that employment interruptions may happen more than once, and for reasons other than childcare alone, for example because of unemployment, further training, an industrial accident, or because a person migrates from another country or changes employers. Above all, life's complexity stems from the fact that people have relationships with each other. All of our constructed biographies, bar one, are married to each other and either live in one household with their spouse when they start drawing their pension, or they retire as divorcees, or both. The following chapters show that different marital matches, and rematches, have a significant impact on an individual's chances of escaping social exclusion.

More specifically all country studies simulate pension entitlements for nine identical, hypothetical men and women and for variations of these. We call our types 'risk biographies' because they were created on the basis that during their adult lives each individual would experience a range of the social risks just discussed. Because of these risks their wages oscillate (see Appendix 1.1 for details), and their average yearly lifetime incomes are generally not much below 40 per cent of the average wage, our social inclusion line, and not much above the average (Table 1.1). All of these individuals started their working lives in 2003 and will retire in 2049, unless they retire early. All country teams thus worked with an identical set of hypothetical men, women and couples on the same wages in relation to the national average.

The following overview of our typology illustrates our types in detail (see also Figure 1.1 and Appendix 1.1 ).

Our typology consists of three women and five men, who are married to each other. Some remain married until retirement, others divorce and remarry and some stay single after separation. This made it possible to include in the simulations derived rights through marriage and divorce payments, and to assess the effect of combined household income on social 


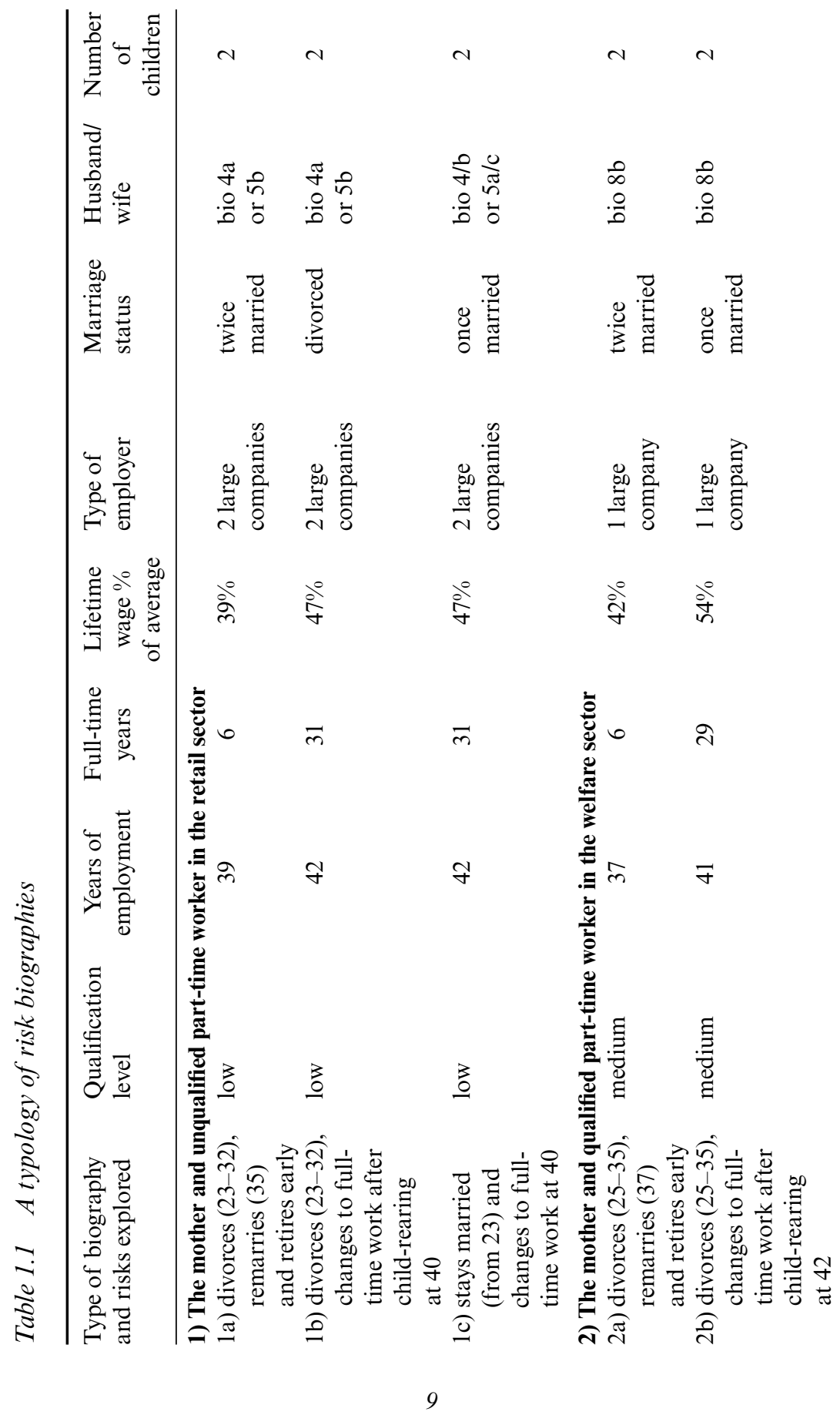




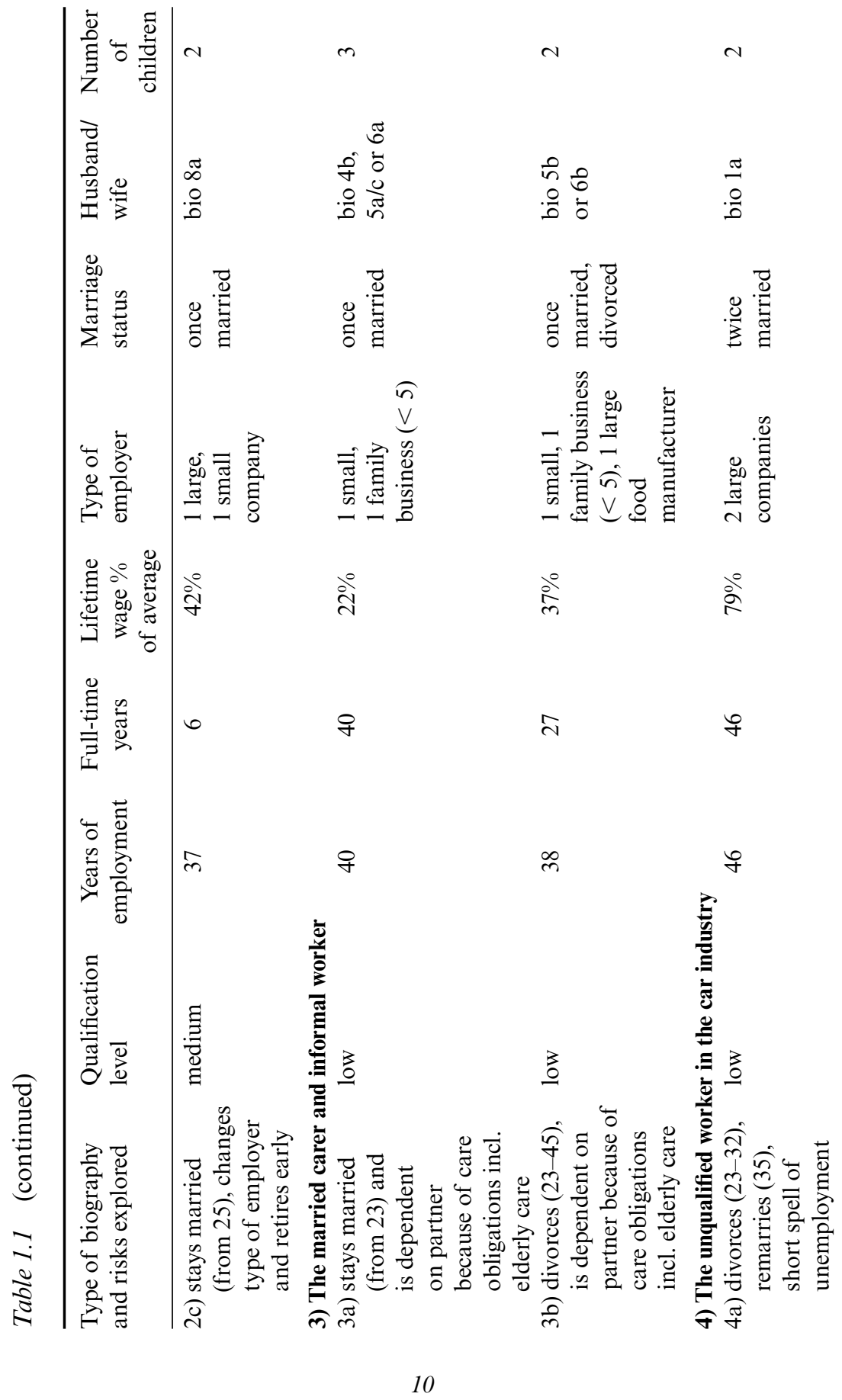




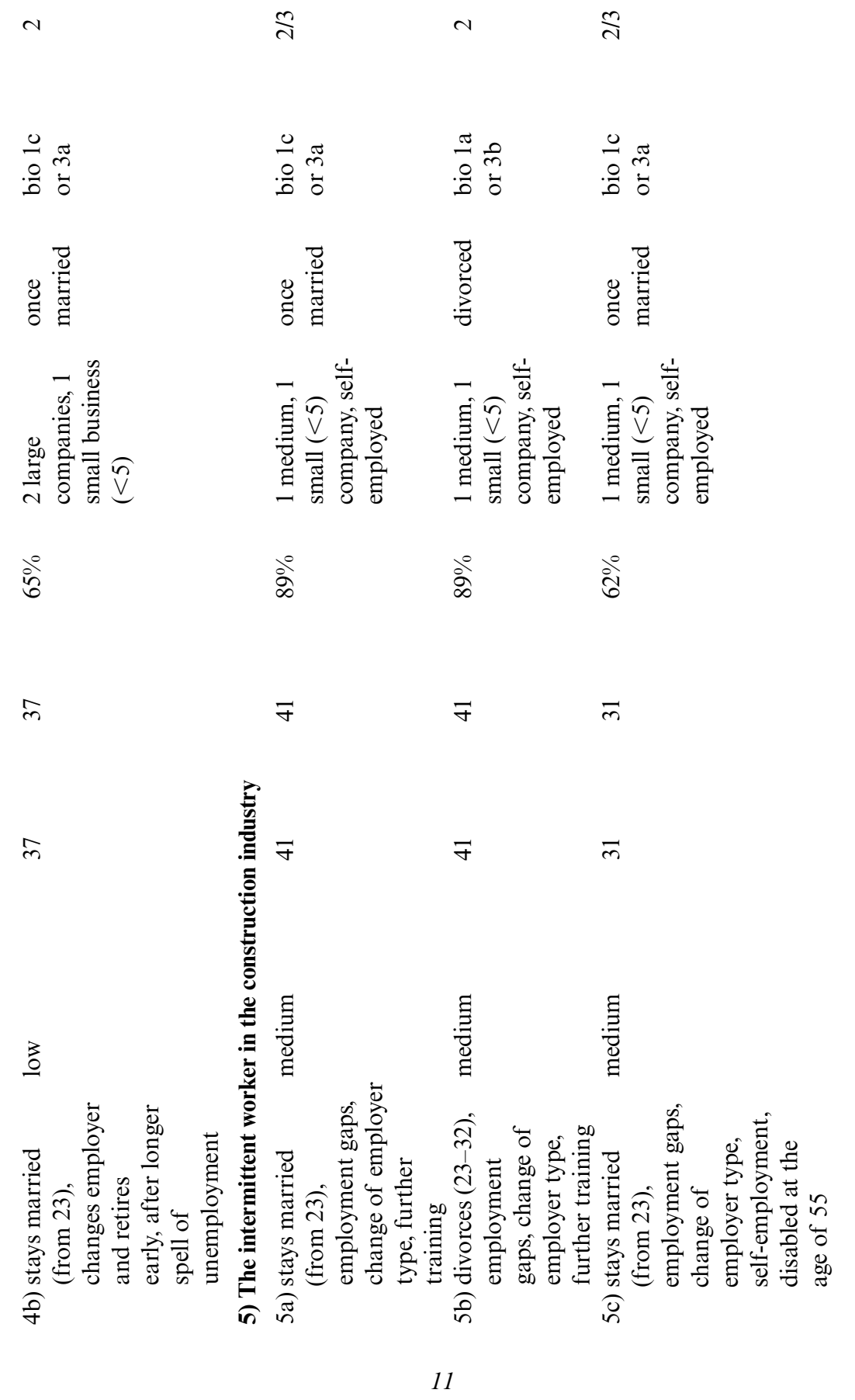




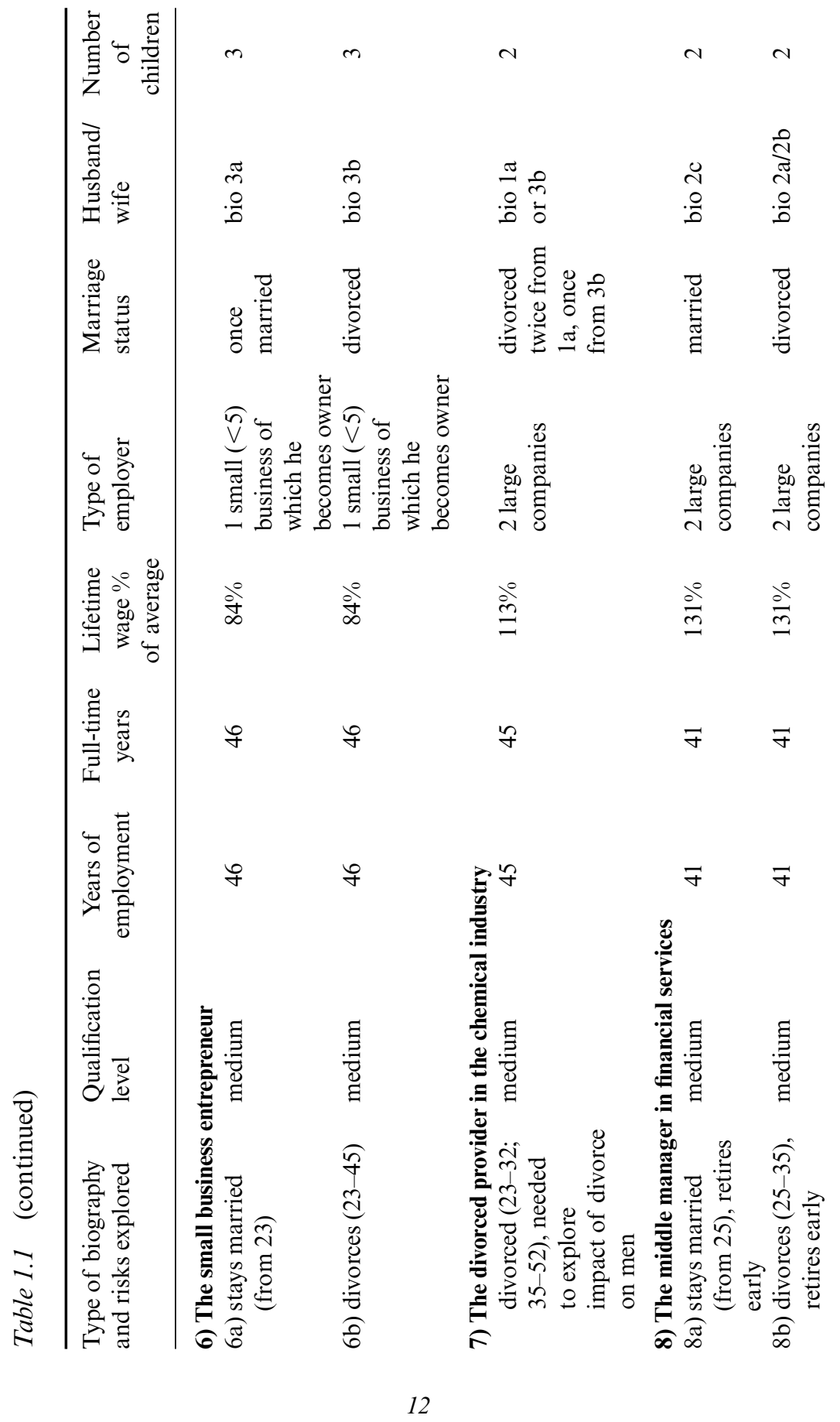




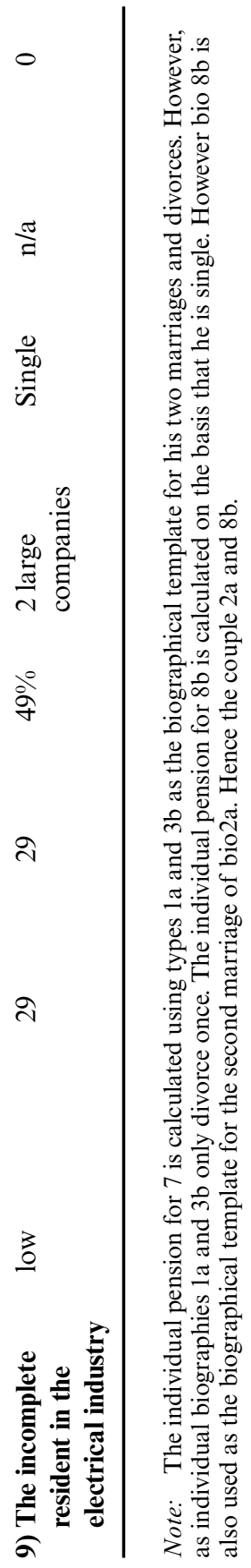




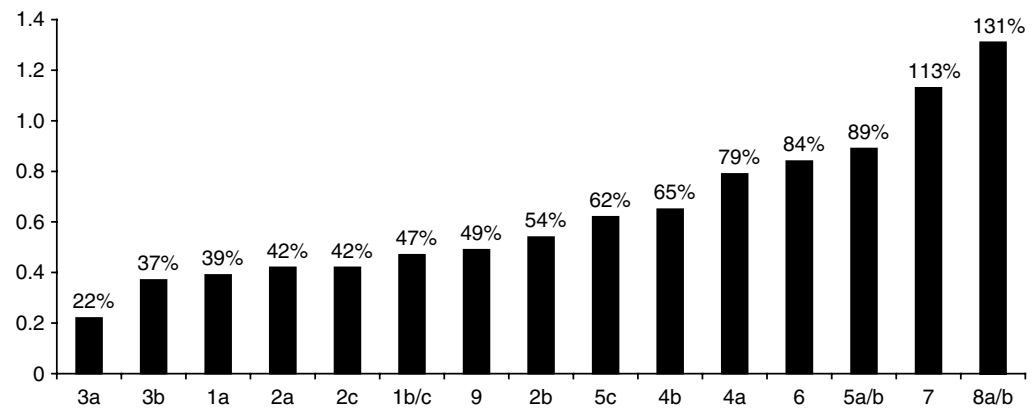

Figure 1.1 Lifetime wage as percentage of average wages of risk biographies

inclusion. In addition we included one individual who never married. Our female types include one unqualified and one medium-qualified worker and mother, and one traditional housewife and carer.

The mother and unqualified part-time worker in the retail sector (bio 1) allows us to explore the impact of a combination of risks: the instability of marriage, a fairly low lifetime income because of low qualifications and part-time work, as well as employment gaps related to care responsibilities for children. The variations in this category have different periods of parttime and full-time work. They are married to an unqualified worker (bio 4) or a worker with an intermittent career (bio 5). Two of these marriages end in divorce.

The risk profile of our second type, the mother and qualified part-time worker in the welfare sector (bio 2), also enables us to assess the role of an employment career that changes to meet the needs of children; two of our variants work full-time only for a few years, one much longer. All are married, but one divorces and remarries. The main difference from the first type is that the level of qualification of the women in this category is higher; they therefore have higher wages. The same applies to their husbands, middle managers in the financial services (bio 8).

The third type, the married carer and informal worker (bio 3), has an independent income below 40 per cent of the average; for protection she relies mostly on her husband, who for part of his working life owns a small business (bio 5 or 6). Her level of formal qualification is low, and even though she works no less than the first two types, she does so mainly as an informal worker in a small family business. One variant has three children, the other has only two. The latter divorces and for the last spell of her working life she is single and employed by a large food manufacturer. Both leave the labour force at the age of 57 to care for their elderly mother. 
Our types 4 to 8 reflect male biographies. They too were chosen to represent low and medium levels of qualification, and where the women experience care-related employment gaps, some of the men are temporarily out of paid work because of unemployment, illness or training. Notwithstanding this gendered ascription, the results for our 'men' and 'women' are applicable to all individuals whose biographies have similar features, irrespective of their gender.

With our fourth type, the unqualified worker in the car industry (bio 4), we aimed to capture the lives of Fordist workers and breadwinners. His level of qualification is low, yet the first variant has a lifelong career as a manual worker in large companies, interrupted only by one year of unemployment between two employers. The second variant is more at risk. He was made redundant in his late thirties, and moved to a small company after that. In his late fifties he was redundant again and he retired early, after five years of unemployment. Both variants are married to retail workers (bio 1), and one has to share pension rights with his divorced spouse.

Our fifth type, the intermittent worker in the construction industry (bio 5), has a medium-level qualification and therefore his wage is higher than the previous type's. His main social risk stems from the fact that he works for three types of smaller company, including his own as a selfemployed worker. Moreover, the third variant becomes disabled after an accident in his mid-fifties, which ends his employment career. All are married to either the unqualified worker (bio 1) or the carer (bio 3).

The small business entrepreneur is our sixth type (bio 6). This person like the previous one has a medium level of qualification, yet his lifetime income is lower because for most of his life he runs his own small business. He is married to the carer (bio 3).

Type 7, the divorced provider in the chemical industry (bio 7), was constructed with the main aim of exploring the extent to which pension-sharing obligations through divorce would increase his social exclusion risk. He is married to the unqualified worker (bio 1) or the carer (bio 3). His employment career is long and uninterrupted, and his income is above the average.

The middle manager in financial services has an even higher salary than the divorced provider and an uninterrupted employment career; we therefore did not expect him to be at risk. We included him as an eighth type for two reasons.

Firstly, this individual illustrates how the better-off do in the national regimes. Secondly, based on theories of social distance (Bottero 2004), we assumed that our qualified part-time worker and mother (bio 2) would marry a partner with a matching level of qualification. In order to calculate her household income, as a married and as a divorced pensioner, we had to include him. 
Our final type is the incomplete resident. This individual has a full-time employment career on half the average lifetime wages, but this is shortened because she or he came to the respective country in their mid-thirties.

\section{SIMULATING PENSION ENTITLEMENTS}

This book assesses pension income from the public pillar, from occupational and from personal pension schemes (detailed assumptions in Appendix 1.2). To this end, the authors of each country study determined what type of public and collective private pension each individual would typically have access to under their national regime.

This was easiest for the public pillar because the conditions for rights accrual are transparent and systematic for all citizens, although it is important to note that we excluded means-tested benefits from the simulations, even those designed specifically for retired citizens. This was for two reasons. On philosophical grounds the group accepted Townsend's argument that means testing by itself can operate as an exclusionary process because it risks stigmatizing those it seeks to assist (Townsend 1979, pp. 879-82). Thus we wanted to focus on non-stigmatizing benefits because they are more consistent with social inclusion. The second reason is that where means testing has been applied it has in most cases encountered problems of take-up, such that significant proportions of those entitled to a particular income level do not actually receive it (see for example Evandrou and Falkingham 2005).

Decisions on non-state provision were more difficult, given that the degree of compulsion varies significantly. In Switzerland coverage by occupational schemes is compulsory and it is quasi-compulsory in the Netherlands. However in Britain, Germany, Italy and Poland occupational schemes are voluntary and coverage is patchier as a result. Given this difficulty we could have included the compulsory part of the pension regime exclusively, which was largely the approach taken by the authors of the study by the OECD (2005b) discussed above. The advantage of this perspective is that only pensions guaranteed to citizens are assessed. However this inevitably means the existing potential of private pensions in countries with voluntarist regimes to contribute to social inclusion would remain unexplored, despite their significance in many cases. Thus we would have had to exclude the very established British and the growing German occupational sector. Given that our study is focused precisely on the potential of the private sector to offer protection, we instead chose to include second pillar schemes in those cases where our individuals would have a prospect to have access to them, while making sure that we also explained what would happen if they did not. As 
a consequence of this methodological choice the reader will find simulations for second pillar coverage for Germany and Britain, but not for Italy, where occupational pensions are still very underdeveloped.

On this basis, country teams calculated for all risk biographies their individual projected gross pension level for 2050, at first only differentiated by public pensions and by collective plans offered through employers. Where individuals divorce, we calculated entitlements according to pensionsharing legislation in each country; in practice this often means that one of the ex-spouses receives entitlements from the other while the other has to share them.

To assess the social inclusiveness of these outcomes, we compare the hypothetical pension of every individual, irrespective of marriage status, with three gradually increasing social inclusion thresholds. The first one measures poverty only. It captures the amount of means-tested social assistance retired citizens with inadequate pension rights would be entitled to claim in each country. This amount also shows what each society has determined as necessary minimum threshold below which no person should fall. National generosity in this regard differs quite strongly between our countries, as the relationship of social assistance and national wage levels show. In four of our cases the poverty line is much lower than 40 per cent of the average wage, a measure that we use as the social inclusion line. Social assistance for the elderly is only near the social inclusion line in Switzerland and, to a slightly lesser extent, in the Netherlands. Finally we use 50 per cent of average wages as a comfortable social inclusion line (see Appendix 1.2 for further explanations). The results give an overview of the combined performance of public pensions and collective plans offered through employers in each country for individual citizens at risk.

Personal savings calculations are added for those individuals not protected sufficiently by public and employer-related schemes. This may be because entitlements are too low, or because citizens do not have access to public or occupational schemes in the first place, such as the self-employed and some carers.

The calculations just described evaluate the inclusiveness of each national regime for individuals at risk. To assess the position of the 11 retired couples we compare their joint pension income with the same gradually increasing inclusion thresholds, adjusted for couples (see Appendix 1.2).

\section{A JUSTIFICATION OF OUR APPROACH}

So far we have made an argument for simulating entitlements of complex rather than simplified biographies, because they are closer to the lives 
people lead, and they are more likely to show where the weaknesses of public and private pension regimes are with regard to social inclusion. This general justification does not however explain how exactly we arrived at the types summarized above. More specifically it needs to be explained why we did not develop types that closely represent 'real lives', and opted instead for a looser construction of hypothetical people.

The first answer to this question is that using risk profiles representative of 'real lives' would have been impossible. To evaluate the inclusiveness of present pension regimes, and thus of recent reforms - this study's main aim - can only be done by simulating future entitlements, and this involves making assumptions about how people's lives will develop. If we had wanted to measure the pension entitlements of real people, we would have had to conduct an analysis of the employment histories of individuals nearing retirement. Yet because pension systems undergo constant change, such an analysis would only partially show the impact of the present regime, and in addition 'echoes of decisions taken at the age of 18 as well as the influence of policies long since reformed' (Rake 1999, p. 223). Given this inevitable effect, the only way to avoid evaluating the impact of cumulative reforms is to freeze programmes and regulations at a set point in time, and to model the consequences (Johnson and Rake 1998, pp. 265-6; Moffit 1999; OECD 2005a, pp. 40-6).

However why did we not attempt to ground our types more firmly in detailed data about the life courses of younger citizens, to make the typology more representative, rather than illustrative? The development of biographies representative of a range of individuals is very difficult, even for one country, not least because of the 'data hunger' of sophisticated microsimulation (Johnson and Rake 1998, pp. 265-6). This appetite would have been voracious in a large comparative project. However even if this problem could have been overcome it would have left us with six national typologies. These would have been useful for national evaluations of the inclusiveness of each system from the perspective of typical British, Dutch, German, Italian, Polish and Swiss citizens, but the comparative aims of the project would have been undermined (Johnson and Rake 1998, pp. 265-6). To gauge the comparative performance of the six regimes it was vital to use a single typology of individuals for all countries.

Based on these considerations our types could not be too specifically grounded in national data. Instead the risks we selected for our individuals had to be typical for the broad social and economic trends in post-industrial societies: the transformation of the 'male breadwinner model', expressed by an increase in mothers' employment, mostly on a part-time basis, and particularly in the expanding service sector, which is apparent also through a destabilization of marriage as expressed by rising divorce rates and an 
increasing rate of births outside marriage and single parents. Moreover we observe a demise of the 'standard worker' with citizens experiencing greater flexibility in the workplace. This increases the need for further training, makes interrupted employment careers more likely and pushes increasing numbers of people towards self-employment. Last but not least, with more flexible borders citizens who move into countries from outside Europe may find themselves with incomplete social rights. These trends are taken from academic analyses (see Armingeon and Bonoli 2006; Castles 2003; Hantrais 1999; Pierson 2001). In addition they reflect many policymakers' expectations of the future, as the following quote from the European Commission's joint report on social protection and social inclusion illustrates:

Demographic changes are compounded by wider changes in cultural values,
social relationships, the organisation of families and the nature of work ... The
increased feminisation of the labour force is reflected in new social demands (for
example, for care facilities for children, elderly and dependent people) and in a
new basis for the division of responsibilities within the household. Notable
changes in family structures have taken place, in terms both of a reduction of
household sizes and increasing diversity - driven by lower rates of partnership
formation and higher rates of dissolution. As a consequence family links are
weakening and, in cases of need, more people have to rely on alternative forms
of support. Finally the working environment has become far more volatile and
heterogeneous. (European Commission 2005a, p. 4)

Some manifestation of these trends is evident in all six countries, yet they also differ. Thus each country has seen an 'increased feminisation of the labour force', although in 2005 employment rates varied substantially. Table 1.2 shows that at least 60 per cent of adult women are in paid work, mostly in the service sector, in Switzerland, the United Kingdom, the Netherlands and Germany. For Dutch and Swiss women this is normally part-time work, while the majority of British and German female employees work full-time. In contrast non-employment is the norm in Italy and Poland, where less than half of adult women have a job, and where selfemployment is more important than in the other countries.

Full-time adult carers continue to play a role in all countries too, and high labour force participation of women in a country does not rule out their existence, just as low female economic activity does not automatically increase their number. It is true that the share of women between 25 and 54 who stay outside the labour force in order to look after their families is highest in Italy, where labour force participation is lowest, but it is not much lower in Switzerland where female employment is highest and rather low in Poland, despite high inactivity.

These figures thus show a diverse country spectrum, but at the same time they demonstrate that each of our female biographies has current relevance 
Table 1.2 Employment and inactivity in the six countries

\begin{tabular}{|c|c|c|c|c|c|c|}
\hline & UK & NL & $\mathrm{CH}$ & GER & IT & PL \\
\hline \multicolumn{7}{|l|}{ Women } \\
\hline Employment rates, 2005 & 65.9 & 66.4 & 70.4 & 59.6 & 45.3 & 46.8 \\
\hline $\begin{array}{l}\text { Part-time }(\%) \text { of female } \\
\text { employment, } 2005\end{array}$ & 43.1 & 75.3 & 58.8 & 44.3 & 25.7 & 14.2 \\
\hline $\begin{array}{l}\text { Employment in services } \\
(\%) \text { of female employment, } \\
2004\end{array}$ & 91.6 & 90.1 & 85.1 & 84.3 & 79.6 & $65.2^{*}$ \\
\hline $\begin{array}{l}\text { Employment in industry } \\
(\%) \text { of female employment, } \\
2004\end{array}$ & 7.9 & $7.8^{*}$ & 12.1 & 14.1 & 17 & $16.5^{*}$ \\
\hline $\begin{array}{l}\text { Self-employment }(\%) \text { of female } \\
\text { employment, } 2004\end{array}$ & 7.6 & 11.2 & 8 & 7.9 & 20 & 26.1 \\
\hline $\begin{array}{l}\text { Average exit age from the labour } \\
\text { force, } 2005^{* *}\end{array}$ & 61 & 61 & 62 & 61 & 61 & 56 \\
\hline $\begin{array}{l}\text { Inactivity rates }(25-54 \mathrm{yrs}) \\
\text { because of personal/family } \\
\text { responsibilities, } 2004\end{array}$ & 13 & 9 & 15 & 12 & 17 & 10 \\
\hline \multicolumn{7}{|l|}{ Men } \\
\hline Employment rates, 2005 & 77.6 & 79.9 & 83.9 & 71.2 & 69.9 & 58.9 \\
\hline $\begin{array}{l}\text { Part-time (\%) of male } \\
\text { employment, } 2005\end{array}$ & 10.6 & 22.6 & 11.8 & 7.7 & 4.5 & 7.7 \\
\hline $\begin{array}{l}\text { Employment in services } \\
(\%) \text { of male employment, } \\
2004\end{array}$ & 72 & 68 & 62.7 & 60.2 & 58 & $44.2^{*}$ \\
\hline $\begin{array}{l}\text { Employment in industry } \\
(\%) \text { of male employment, } \\
2004\end{array}$ & 26.7 & $27.7^{*}$ & 32.7 & 37 & 36.9 & $35.7^{*}$ \\
\hline $\begin{array}{l}\text { Self-employment (\%) of male } \\
\text { employment, } 2004\end{array}$ & 17.2 & 16.4 & 10.6 & 13.3 & 28.6 & 31.4 \\
\hline $\begin{array}{l}\text { Average exit age of men } \\
\text { from the labour force, } \\
2005^{* *}\end{array}$ & 63 & 61 & 64 & 61 & 61 & 60 \\
\hline $\begin{array}{l}\text { Inactivity rates }(25-54 \mathrm{yrs}) \\
\text { because of personal/family } \\
\text { responsibilities, } 2004\end{array}$ & 0 & 0 & 0 & 0 & 0 & 0 \\
\hline
\end{tabular}

Notes:

* Figures for 2003

** Exit age for Italy, Switzerland: 2003

Sources: http://epp.eurostat.cec.eu.int; European Commission (2005b); CH: Swiss Federal Statistical Office (2005a) 
for each of our countries. By the same token with regard to men despite some variation - a high rate of part-time work in the Netherlands and a very low rate in Italy, very low participation rates in Poland and very high in Switzerland, as well as very high levels of self-employment in Poland and Italy - the male norm, reflected by our typology, is still to be a full-time worker in either the service or the manufacturing sector who does not take time off to take on family responsibilities.

The majority of our hypothetical individuals retire at the age of 65 ; early retirement, at 60 , is an exception. Those with lower qualification levels enter the labour market at 18 , those with medium-level qualifications at 20 . While these assumptions do not reflect the decisions of some governments to raise the pension age above 65 , they are higher than the current real average exit age from the labour force in all our countries. The protracted nature of the process of raising the real retirement age is illustrated by the fact that the EUwide target set by the Stockholm European Council in 2001 to raise employment rates of older citizens between 55 and 64 by at least 50 per cent by 2010 so far has only been met by Britain (56 per cent) and Switzerland (65 per cent) and that the Commission is concerned the target will not be reached by many unless countries increase their efforts (European Commission 2005a, pp. 10, 34; European Commission 2006, pp. 28-9; OECD 2005a).

The growing importance of more 'volatile' working environments is captured in our typology by periods of unemployment and further training, which several of our male types encounter. This reflects current trends; Table 1.3 shows that there is a chance either event will be experienced in any of our countries, yet the likelihood varies quite a lot. Lifelong education is significant in Switzerland, Britain and the Netherlands, while unemployment is low. Conversely unemployment is very high in Poland and substantial in Germany and Italy, while adults in these three countries have fewer opportunities to be in training programmes. It is noticeable that female unemployment rates are higher than those of men in all countries but Britain. This increased social risk that women bear is reflected in our typology by the greater employment gaps our hypothetical women are subjected to.

An indicator for the occurrence of our ninth type, the incomplete resident, is also included in Table 1.3. It shows that the highest share of nonnationals of the population by far live in Switzerland and the lowest in Poland. These figures include non-nationals from EU countries whose pension rights are protected by EU legislation, but more differentiated data is not available.

Finally divorce plays an important role for our hypothetical biographies. This is reflected by real current divorce figures shown in Table 1.4. Again they vary a lot; with marriage more stable in Italy and Poland and most 
Table 1.3 Employment interruptions in the six countries

\begin{tabular}{lcccccc}
\hline & UK & NL & CH & GER & IT & PL \\
\hline $\begin{array}{l}\text { Men } \\
\text { \% of 25-64-year-olds in } \\
\quad \text { education and training, 2004 } \\
\begin{array}{l}\text { \% of 25-year-olds and over } \\
\text { unemployed, 2005 }\end{array}\end{array}$ & 24 & 17 & 30 & 8 & 6 & 5 \\
$\begin{array}{l}\text { Women } \\
\text { \% of 25-64-year-olds in } \\
\text { education and training, 2004 }\end{array}$ & 34 & 18 & 27 & 7 & 7 & 6.8 \\
$\begin{array}{l}\text { \% of 25-year-olds and over } \\
\text { unemployed, 2005 }\end{array}$ & 3 & 4.4 & 4.5 & 9.6 & 8.4 & 16.6 \\
$\begin{array}{l}\text { Non-nationals of national } \\
\text { population around 2004 }\end{array}$ & 4.7 & 4.3 & 20 & 8.9 & 3.4 & 1.8 \\
\hline
\end{tabular}

Sources: http://epp.eurostat.cec.eu.int; CH: Swiss Federal Statistical Office (2005b)

Table 1.4 Divorce in the six countries

\begin{tabular}{lccc}
\hline Divorces per 100 marriages & 1985 & 1995 & 2002 \\
\hline United Kingdom & 44.6 & 52.8 & 50.5 \\
Netherlands & 41.1 & 41.9 & 39.5 \\
Switzerland & 29.4 & 38.5 & 40.8 \\
Germany & 36.1 & 39.4 & 52.1 \\
Italy & 5.2 & 9.3 & 15.4 \\
Poland & 18.4 & 18.4 & 23.7 \\
\hline
\end{tabular}

Source: Eurostat_http://epp.eurostat.cec.eu, UK figures for 2002 are from 2000

fragile in Germany and the UK, but the figures show that in all countries, except for the Netherlands, divorce has been on the rise over the last 20 years.

The discussion above shows that all types resonate with the situation in the six countries. Complete mismatches do not exist, but it is important to keep in mind that certain life course events are currently less likely in some countries than in others. This issue will be further discussed as it arises in the individual country case-studies. With regard to the book's main questions the country characterizations indicate that, were the conditions of 2004/05 to continue into the future, Poland, Italy and Germany would probably face greater problems insuring their populations against social 
risks in retirement than Switzerland, the Netherlands and the United Kingdom, simply because a larger share of their populations - women and men - are economically inactive or unemployed. The country studies will show whether and to what extent this is the case and what type of systems are in place to deal with these trends.

\section{WHY THESE SIX COUNTRIES?}

\section{Private Pension Veterans}

The countries included in this book allow us to study the relationship between private pensions and social inclusion against diverse institutional backgrounds. They can be grouped according to either their 'Beveridgean' or 'Bismarckian' legacies, which determined whether they developed multipillar systems fairly early during the second half of the twentieth century or whether they were dominated by one public programme (Bonoli 2003, p. 400).

The Swiss, British and Dutch pension systems have historically been based on a first, revenue-funded part, paid as flat rate benefit, which covers at most basic needs (Bonoli 2003, pp. 400-402). However despite this structural similarity there are important differences between the first pillar arrangements in each country. In Switzerland a public pay-as-you-go (PAYG) pension to meet basic needs was introduced in 1946 and was moderately earnings-related, and universal. In contrast the Dutch public PAYG pension, introduced in 1959, is a basic flat rate benefit for all seniors based on residence. The British Basic State Pension, introduced in 1946, is different again: it is flat rate like the Dutch pension but like Swiss state provision is social insurance based. It has never risen above subsistence level (Hannah 1986, pp. 54, 59), although in 1975 a serious attempt was made to create a more inclusive state pension through the introduction of the State Earnings Related Pension Scheme. ${ }^{4}$ In the changed political climate of the 1980s this system was cut down again before it could mature, but a new State Second Pension is still likely to provide an important supplementary income to future retirees.

Partly because of the relatively low level of state provision in each country, substantial occupational pension systems have developed, initially on a voluntary basis. Because the level of the first pillar was regarded as insufficient by higher earners, interest grew in pensions above this level. This voluntary development of occupational pension is also likely to have been the result of employers, particularly the larger and thus richer ones, using occupational provision as a tool to ensure the recruitment and retention of 
workers, particularly skilled ones, the early retirement of older surplus labour, and to manage the relationship with trade unions (Clark et al. 2007, p. 19; Green et al. 1984; Hannah 1986, pp. 18-30; Hart 1984, pp. 45, 50-51; Hawkesworth 1977; Mares 2001, pp. 195-6; Myles and Pierson 2001; Rein 1996, p. 40; Sass 1997, pp. 18-37; Whiteside 2003, p. 33, 2006). In each country government intervention has further encouraged occupational provision through fiscal incentives (Hannah 1986, p. 38; Sinfield 2000, p. 141; Titmuss 1958). ${ }^{5}$

However although the early development of occupational pension systems in all of our veteran countries was initially voluntary they now differ considerably regarding the degree of compulsion imposed on employers and employees. In Switzerland, in 1985, occupational pensions became compulsory for employees above a fixed earnings threshold, with a minimum standard set for benefits. This reform followed strong pressure from left-wing parties expressed through the Swiss federal referendum system. They wanted the income replacement benefits of occupational pensions to be distributed on a more universal basis (Bonoli 2004). However the system does not cover the self-employed and is less inclusive with regard to women, because they are more likely to fall below the earnings threshold (Bonoli 2007; Chapter 4).

In the Netherlands, moves towards more general coverage of occupational provision occurred much earlier as part of broader corporatist arrangements (Whiteside 2006). Legislation enacted in 1947 prescribed that, where the Ministry of Social Affairs adjudged it appropriate, collective agreements about pensions in one company had a binding effect for the respective sector as a whole. This became particularly relevant during the 1980s and 1990s when the second Dutch pillar expanded greatly, taking pressure off the public system (see also Clark and Whiteside 2003, p. 145; Haverland 2001, pp. 309, 314). Yet while the state sets the regulatory framework for occupational schemes, the specific conditions of sector-wide pension plans are negotiated between employers and trade unions (Anderson 2007; van Riel et al. 2003, p. 67). As in Switzerland the system generally does not cover the self-employed but it is more open for part-time workers than the Swiss and therefore more inclusive overall. In 2005 it covered more than 90 per cent of the workforce (OECD 2005a, p. 152).

The British system is the most voluntarist regime in this group (Pierson 1994, pp. 53-73). Coverage has always been selective because occupational pension provision is not compulsory (Clark 2000). It has been provided mainly, but not exclusively, for those with full-time earnings, stable employment careers, likely to work in private companies or the public sector (Baldwin 1990, pp. 239-40, 243; GAD 2003, p. 18; Ginn 2003, pp. 13-14; Meyer and Bridgen forthcoming 2008) and has traditionally excluded those 
in small businesses, or with less stable contracts. Until the 1990s part-time workers, too, were much more likely not to be members (Groves 1983, p. 40; Groves 1987, pp. 209, 211), but as in the Netherlands, this has begun to change through improved equal pay and sex discrimination legislation (Mazey 1998, pp. 139-44).

Thus Switzerland, the Netherlands and the United Kingdom all have a mature occupational pension system in addition to the first pillar, yet the differences are also significant. Firstly while the Swiss and the Dutch state pensions aimed to prevent poverty, the British has been below the poverty line, creating greater dependency on other sources of income, such as occupational or private provision or other means-tested benefits. Secondly coverage through occupational schemes in the Netherlands and Switzerland has been much higher than in Britain, because of a greater degree of compulsion in the former two countries which nevertheless allowed for both regimes to exclude the self-employed. Swiss and Dutch second pillars are enforced through legislation, with the difference that Swiss businesses have to meet minimum standards, which they can exceed if they wish, while Dutch employers and trade unions have greater scope to negotiate scheme details. Britain in contrast allows us to study the impact of an essentially voluntarist regime.

\section{Private Pension Newcomers}

Until the late 1990s Germany, Italy and Poland fitted into the classic Bismarckian mould. After extending their scope and generosity from the late 1950 s, by the end of the 1960s state-regulated and compulsory pay-as-you-go pension systems existed for all employed citizens in the three countries. These were largely funded through social insurance contributions from employers and employees in Germany and Italy, and through taxes in Poland. Pension entitlements were dependent on length of employment career and were designed to preserve pre-retirement standards of life for full-time workers, although the link between earnings and benefits in Poland and Italy was not always transparent with some workers privileged over others, for example Polish miners and steelworkers. In the 1970s the Italian public pension replaced 80 per cent of final earnings for a full-time worker after 40 years, while this rate was 70 per cent in Germany and 51 per cent in Poland. In addition means-tested social assistance benefits had been introduced in order to protect those without sufficient insurance from poverty (Chapter 5, 6, 7 in this book; Ferrera and Jessoula 2007; GUS 2003, p. 447; Müller 1999; Stroinski 1998, p. 30). Funded systems as well as voluntary arrangements through companies or individuals only played a small role, if any. They were crowded out by the strong public sector (Bonoli 2003, p. 400; Haverland 2001, p. 312). 
During the 1990s reform pressures mounted because all three countries suffered from chronic high unemployment and low activity rates, driving up the social insurance contribution for the economically active population and for employers (Table 1.3). It is fair to say that Poland's as well as Germany's economic problems were influenced too by the collapse of the Eastern Bloc, leading to a fundamental change in both societies, but particularly in Poland and the East German New Länder (Schulze and Jochem 2007). To make matters worse, Germany, Italy and Poland are affected particularly strongly by ageing populations; they are amongst the countries with the lowest fertility rates in Europe and thus their predicted dependency ratios for the elderly population were comparatively high too, increasing the need for pension reform. Against this background governments in all three countries felt compelled to implement fundamental changes during the 1990s. These are detailed in Chapters 5, 6 and 7. However, briefly put, they involved the sweeping away of the principle of the first pillar as guarantor of the customary standard of living for the long-term employed. They also led to a lowering of public pensions and to the strengthening of actuarial principles in the first pillar in Italy and Poland, which now grant relatively insignificant compensation for citizens with care responsibilities or for part-time workers. Thus German, Italian and Polish citizens are now expected to depend more strongly on the less redistributive second and third pillars in order to fill the gap that decreased public pension levels are likely to leave. So far in all countries reliance has been placed on the voluntarism of non-state actors. Incentives in the form of tax and subsidies have been created for citizens as well as for corporate actors to invest voluntarily in occupational or personal schemes in order to make up for the public shortfall.

This brief overview demonstrates that our three countries share a Bismarckian legacy and that all have recently made a sudden private turn. However it also became apparent that 'privatization' looks rather different for each of them. In moving away from predominantly statist systems they have each chosen a different mix of public and private provision. Our study will show how these different approaches affect the way these three countries fare in producing pension outcomes consistent with social inclusion.

In conclusion our group comprises three countries that already had substantial funded components, and therefore have been able to adjust to current circumstances by more incrementally reforming their existing programmes. The other three countries have recently implemented substantial changes to their pension systems, introducing funded elements into mature pay-as-you-go schemes. As a result of these developments comparing the six pension regimes as they exist today, the systematic publicprivate differences between the two groups disappear on the level of pro- 
grammes and legislation, and a continuum of regimes takes their place which mix in various ways pensions with public and private aspects. Where different countries might lie on this continuum depends on the principle chosen to organize it. In this regard one important issue is the role of the state either as provider or regulator. At one end of a continuum organized on this basis, we would find Switzerland and the Netherlands where state provision is inclusive and redistributive and where the coverage of occupational schemes is broad in scope because of legislation, but where employers and trade unions still have some freedom to use occupational schemes to further their own interests. At the other end of this type of continuum are Germany and the United Kingdom. Here state provision is lower and the regulation of occupational and personal schemes is based on setting standards and offering incentives, leaving it to other societal actors to decide whether occupational provision is supplied. In the middle, we find Italy and Poland, which are similar in that the role of the state in pension provision remains dominant, but where differences exist in the state's engagement with non-state providers, Italy having moved more in this direction than Poland. However if we chose instead to organize our continuum in relation to the size and generosity of the state pay-as-you-go system, and thus the role left to non-state provision in preventing social exclusion, our order would be Italy, Switzerland, the Netherlands, Germany and the UK, followed by Poland as the country with the smallest pay-as-you-go pension in our group. In terms of assessing the combination(s) of public and private approaches most consistent with the aim of social inclusion in retirement, such distinctions are, as will be seen, extremely important.

We can therefore say that by selecting these six countries we have chosen examples from two distinct institutional legacies which today show a broad range of combinations of private and public elements. Our aim is to see which combinations are most consistent with social inclusion.

\section{SPENDING PATTERNS AND AGE PROFILE}

One would expect that Beveridgean and Bismarckian trajectories would also generate two distinct spending patterns, with higher public expenditure displayed by the newcomers and greater engagement in privately owned pension funds in the veteran group.

However as Table 1.5 indicates, countries with mature three pillar systems do not necessarily spend less money on public pensions than those with predominantly public pillars. ${ }^{6}$ The differences between some of the 'veteran' and 'newcomer' group were small in 2003 but they become insignificant when we take dependency rates into account. Italy and Poland 
Table 1.5 Public expenditure on pensions in the six countries

\begin{tabular}{lcccccc}
\hline & UK & NL & CH & GER & IT & PL \\
\hline $\begin{array}{c}\text { Public expenditure on pensions, } \\
\begin{array}{c}\text { current prices (\% of GDP), 2003 } \\
\text { Old age dependency ratio, 2004 }\end{array}\end{array}$ & 11.0 & 12.6 & 13.2 & 13.4 & 15.1 & 14.3 \\
\hline
\end{tabular}

Sources: Expenditure: Eurostat_http://epp.eurostat.cec.eu; Old Age Dependency Ratio (Population 65 and over as percentage of population 15-65): EPC (2006) Annex;

Switzerland: figures for 2000 from Bundesamt für Sozialversicherungen (2006): T14.

are certainly top spenders, but the former also has the highest dependency rates in the group. German expenditure is almost the same as two veteran countries, the Netherlands and Switzerland, but on the basis of a higher dependency ratio than either of them. This suggests that the Dutch and Swiss public systems are more generous than the German system and almost equal in generosity to the Italian system, despite the fact that they also have large private pillars. Thus the only 'veteran' country that does indeed display low expenditure on public pensions is Britain, but even here the difference is not great. We therefore conclude that while a three pillar regime may be accompanied by low public spending on pensions under certain circumstances, there are no reliable systematic differences in public expenditure between the two groups.

When we consider the role of funded pensions in each country through the amount invested by pension funds and life insurance companies the anticipated difference between veterans and newcomers is confirmed more clearly (Figure 1.2). ${ }^{7}$ Due to the mature funded systems of Switzerland, the Netherlands and the United Kingdom investments were worth more than these countries' GDP in 2004, and far above the OECD average (OECD 2005d, p. 3). In fact Switzerland and the Netherlands, together with Iceland, are the countries with the strongest-funded pension markets globally (OECD 2005d). Britain is somewhat less developed, probably because second pillar coverage is patchier, due to its voluntarist nature, and therefore less money is invested than in the quasi-compulsory occupational pensions sectors of Switzerland and the Netherlands (OECD 2005b). However the fact that British life insurance investment is higher than anywhere else suggests that individuals have taken the initiative to make up for the shortcomings of the public and occupational sectors; as we will argue in Chapter 2, these are unlikely to be citizens on lower incomes, though.

In summary it is true that the three countries with a long history of funded pensions invest large amounts of their national wealth in these systems; this is also true under the conditions of British voluntarism, albeit 


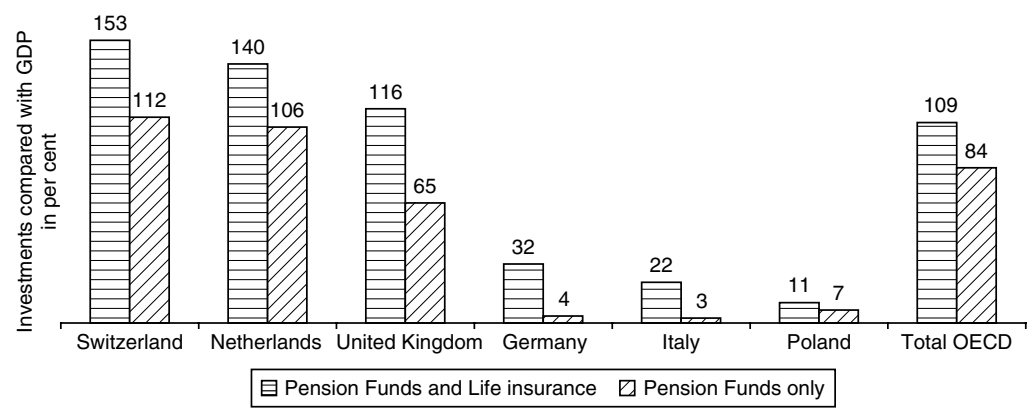

Notes: CH/NL 2003 data used for 2004; CH: 2003 data preliminary estimates, http//www.oecd.org/document/46/0,2340,en_2649_34853_36091822_1_1_1_1,00.html, accessed August 2006

Figure 1.2 Total assets for pension funds and life insurance investments as a percentage of GDP in 2004 in the six countries

to a lesser extent. Funded schemes are growing fast in the newcomer group, too (OECD 2005d), yet levels are still comparatively low.

\section{Overview}

As we have just shown, in spite of very different legacies, in 2006, the pension systems of the privatization veterans and the privatization newcomers look less different. This is because the latter group has followed the trend for multi-pillar systems so dominant in highly developed countries. Against this background the main aim of this study is to explore what risk of social exclusion public-private pension regimes pose for citizens who lead complex lives, which include risks typical for post-industrial society. In this introduction we have sought to explain the rationale behind this question and to justify to the reader why, to examine it, we use microsimulation of retirement income of illustrative individuals.

In the following, each of the case-studies is structured in the same way. First they characterize all pillars of their current pension regime, considering in particular how occupational schemes and private savings programmes are regulated by the state and/or the trade unions and to what extent such non-state actors can engage in this area on a voluntary basis. In a second step each country study calculates how socially inclusive their national regimes are on the basis of the microsimulation methodology outlined above. Finally consideration is given to the extent to which the weaknesses in each country's performance are being addressed in the current policy debate. On the basis of the responses provided to these questions in the country chapters, the final 
chapter assesses whether it is possible to identify public-private pension mixes which successfully provide socially inclusive outcomes.

\section{NOTES}

1. This research generally relates to the pension systems in each country as they operated in 2003, when this research started. However in some countries (for example Germany and Italy) the impact of ongoing reform processes on system design was anticipated. This is detailed in the country chapters.

2. This has occurred notwithstanding a recognition of the difficulties involved in defining exactly 'what should be considered public or private'. See Esping-Andersen (1990) p. 91; see also Shalev (1996); an exception was van Gunsteren and Rein (1985).

3. The study by the OECD (2005a) simulates pension levels for individuals starting work in 2002 in all OECD countries by different income levels. Another big difference to our study is that only mandatory pension schemes and those with very broad coverage are included, paying less attention to the British second pillar for example. Secondly, the OECD focuses on replacement rates of pensions, and does not compare all pillar entitlements with social inclusion lines, as we do, this is also true for the Social Protection Committee Report commissioned by the EU on projected pension replacement rates. Thirdly, the OECD takes into account gross and net figures, that is it assesses the impact of tax and social insurance. We use this study to compare and discuss our results.

4. An earnings-related pension was introduced in 1961 but this was insubstantial and designed mainly to provide additional contributions to reduce the Exchequer cost of pensions (see Bridgen 2006).

5. However in recent years government regulation has also increased employers' costs and smothered their willingness to engage in occupational pensions (Clark 2003, p. 234; Cutler and Waine 2001, pp. 108-9; Quadango and Hardy 1996; Ross and Wills 2002; Sass 1997, pp. 233-8; Whiteside 2003, pp. 41-2).

6. These figures include as public expenditure on pensions the contracted-out national insurance rebate used in Britain to fund private alternatives to the State Second Pension.

7. To assess the approximate role of funded pensions in each of our countries, we use the OECD's figures on the sum of investments of pension funds and of life insurance companies. These figures comprise assets of most occupational and personal pensions savings in the public and private sectors of the countries we studied (OECD 2005c, 2005d). The caveat here is that these figures do not include book reserves, that is, 'sums entered in the balance sheet of the plan sponsor as reserves or provisions for occupational pension plan benefits' (OECD 2005b, p. 41). In our group book reserves are mainly used in Germany, where as a consequence real pension claims of households are higher than suggested by pension fund and life insurance investments (OECD 2005d; Chapter 5).

\section{BIBLIOGRAPHY}

Anderson, K.M. (2007), 'The Netherlands: political competition in proportional system', in E.M. Immergut, K.M. Anderson and I. Schulze (eds), Handbook of West European Pension Politics (pp. 713-57), Oxford: Oxford University Press.

Aposori, E. and Millar, J. (eds) (2005), The Dynamics of Social Exclusion in Europe: Comparing Austria, Germany, Greece, Portugal and the UK, Cheltenham, UK and Northampton, MA, USA: Edward Elgar. 
Armingeon, K. and Bonoli, G. (eds) (2006), The Politics of Post-Industrial Welfare States, Oxford: Routledge.

Augusztinovics, M. (2002), 'Issues in pension system design', International Social Security Review, 55(1), 21-35.

Baldwin, P. (1990), The Politics of Social Solidarity: Class Bases of the European Welfare State 1875-1975, Cambridge: Cambridge University Press.

Barnes, M., Heady, C., Middleton, S., Millar, J., Room, G., Papadopoulos, F. and Tsakloglou, P. (2004), Poverty and Social Exclusion in Europe, Cheltenham, UK and Northampton, MA, USA: Edward Elgar.

Barr, N. (2000), 'Reforming pensions: myths, truths and policy choices', IMF working paper WP/00/139, Washington, DC: IMF.

Behrendt, C. (2000), 'Private pensions: a viable alternative? Their distributive effects in comparative perspective', International Social Security Review, 53(3), 3-26.

Berthoud, R. and Iacovou, M. (eds) (2004), Social Europe: Living Standards and Welfare States, Cheltenham, UK and Northampton, MA, USA: Edward Elgar.

Bonoli, G. (2003), 'Two worlds of pension reform in Western Europe', Comparative Politics, 35(4), 399-416.

Bonoli, G. (2004), 'The institutionalisation of the Swiss multipillar pension system', in M. Rein and W. Schmähl (eds), Rethinking the Welfare State: The Political Economy of Pension Reform (pp. 102-21), Cheltenham, UK and Northampton, MA, USA: Edward Elgar.

Bonoli, G. (2007), 'Switzerland: development and crisis of a multipillar pension system', in E.M. Immergut, K.M. Anderson and I. Schulze (eds), Handbook of West European Pension Politics (pp. 203-47), Oxford: Oxford University Press.

Bonoli, G., George, V. and Taylor-Gooby, P. (2000), Towards a Theory of Retrenchment, Cambridge: Polity Press.

Bonoli, G. and Shinkawa, T. (eds) (2005), Ageing and Pension Reform Around the World: Evidence from Eleven Countries, Cheltenham, UK and Northampton, MA, USA: Edward Elgar.

Bottero, W. (2004), Stratification: Social Division and Inequality, London: Routledge.

Bridgen, P. (2006), 'A straitjacket with wriggle room: the Beveridge Report, the Treasury and the Exchequer's pension liability 1942-59', Twentieth Century British History, 17(1), 1-25.

Bridgen, P. and Meyer, T. (2005), 'When do benevolent capitalists change their mind? Explaining the retrenchment of defined benefit pensions in Britain', Social Policy and Administration, 39(4), 764-85.

Bundesamt für Sozialversicherungen (2006), Statistiken zur Sozialen Sicherheit. AHV Statistik 2006 Tabellenteil. Bern.

Burchardt, T. (1997), 'Boundaries between public and private welfare: a typology and map of services', London: CASE paper, CASE/2, LSE.

Casey, B. and Yamada, A. (2003), 'The public-private mix of retirement income in six OECD countries: some evidence from micro-data and an exploration of its implications', in M. Rein and W. Schmähl (eds), Rethinking the Welfare State: The Political Economy of Pension Reform, Cheltenham, UK and Northampton, MA, USA: Edward Elgar.

Castles, F.G. (2003), 'The world turned upside down: below replacement fertility, changing preferences and family-friendly public policy in 21 OECD countries', Journal of European Social Policy, 13(3), 209-27. 
Clark, G. (2000), Pension Fund Capitalism, Oxford: Oxford University Press.

Clark, G. (2003), European Pensions and Global Finance, Oxford: Oxford University Press.

Clark, G., Munnell, A. and Orszag, M. (2007), 'Pensions and retirement income in a global environment', in G. Clark, A. Munnell and M. Orszag (eds), The Oxford Handbook of Pensions and Retirement Income (pp. 10-28), Oxford: Oxford University Press.

Clark, G. and Whiteside, N. (eds) (2003), Pension Security in the 21st Century, Oxford: Oxford University Press.

Cutler, T. and Waine, B. (2001), 'Social insecurity and the retreat from social democracy: occupational welfare in the long boom and financialisation', Review of International Political Economy, 18(1), 96-118.

Dimson, E., Marsh, P. and Staunton, M. (2002), Triumph of the Optimists: 101 Years of Global Investment Returns, New Jersey: Princeton University Press.

Disney, R. and Johnson, P. (eds) (2001), Pension Systems and Retirement Incomes Across OECD Countries, Cheltenham, UK and Northampton, MA, USA: Edward Elgar.

Drakeford, M. (2000), Social Policy and Privatisation, Harlow: Pearson Education.

DWP (Department of Work and Pensions) (2002), Simplicity, Security and Choice: Working and Saving for Retirement, London: HMSO.

Economic Policy Committee (EPC) (2006), The Impact of Ageing on Public Expenditure: Projections for the EU25 Member States on Pensions, Health Care, Long-term Care, Education and Unemployment Transfers (2004-2050), Report prepared by the Economic Policy Committee and the European Commission (DG ECFIN), Brussels.

Esping-Andersen, G. (1990), The Three Worlds of Welfare Capitalism, Princeton, NJ: Princeton University Press.

European Central Bank (2004), Statistics Pocket Book, December, http://www. ecb.eu/pub/pdf/stapobo/spb200412en.pdf.

European Commission (2003), Adequate and Sustainable Pensions. Joint report by the Commission and the Council. DG Employment and Social Affairs, Brussels: European Communities.

European Commission (2005a), Communication from the Commission to the Council, the European Parliament, the European Economic and Social Committee and the Committee of the Regions. Joint Report on Social Protection and Social

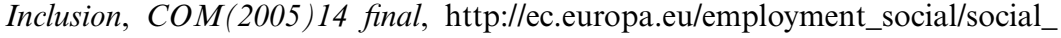
inclusion/docs/com_en.pdf, accessed August 2006.

European Commission (2005b), Employment in Europe, http://ec.europa.eu/ employment_social/employment_analysis/employ_2005_en.htm, accessed August 2006.

European Commission (2006), Employment in Europe 2006, Brussels: European Commission.

European Council (2006), New Common Objectives 2006, http://ec.europa.eu/ employment_social/social_protection/pensions_en.htm, accessed 17 Jan 2007.

Evandrou, M. and Falkingham, J. (2005), 'A secure retirement for all? Older people and New Labour', in J. Hills and K. Stewart (eds), A More Equal Society? New Labour, Poverty, Inequality and Exclusion (pp. 167-88), Bristol: Policy Press.

Ferrera, M. and Jessoula, M. (2007), 'Italy: a narrow gate for path-shift', in E.M. Immergut, K.M. Anderson and I. Schulze (eds), Handbook of West European Pension Politics (pp. 396-498), Oxford: Oxford University Press. 
GAD (2003), Occupational Pension Schemes 2000, Eleventh Survey by the Government Actuary, London: Government Actuary's Department, www.gad. gov.uk/Publications/docs/opss 2000_final_results_final_7april2003.pdf, accessed October 2005.

Ginn, J. (2003), Gender, Pensions and the Life Course: How Pensions Need to Adapt to Changing Family Forms, Bristol: Policy Press.

Goodin, R.E., Headey, B., Muffels, R. and Dirven, H-J. (1999), The Real Worlds of Welfare Capitalism, Cambridge: Cambridge University Press.

Green, F., Hadjimatheou, G. and Smail, R. (1984), 'Unequal fringes', Occasional Papers on Social Administration No. 75, London: NCVO.

Groves, D. (1983), 'Members and survivors: women and retirement-pension legislation', in J. Lewis (ed.), Women's Welfare, Women's Rights (pp. 18-63), London and Canberra: Croom Helm.

Groves, D. (1987), 'Occupational pension provision and women's poverty in old age', in C. Glendinning and J. Millar (eds), Women and Poverty in Britain (pp. 199-220), Brighton: Wheatsheaf.

GUS (2003), Historia Polski w liczbach, Warsaw: t.I - Panstwo i Spolecznenstwo.

Hannah, L. (1986), Reinventing Retirement: The Development of Occupational Pensions in Britain, Cambridge: Cambridge University Press.

Hantrais, L. (1999), 'Socio-demographic change, policy impacts and outcomes in social Europe', Journal of European Social Policy, 9(4), 291-309.

Hart, R.A. (1984), The Economics of Non-wage Labour Costs, London: George Allen \& Unwin.

Haverland, M. (2001), 'Another Dutch Miracle? Explaining Dutch and German pension trajectories', Journal of European Social Policy, 11(4), 308-23.

Hawkesworth, R.I. (1977), 'Fringe benefits in British industry', British Journal of Industrial Relations, 15(3), 396-402.

Hyde, M., Dixon, J. and Drover, G. (2003), 'Welfare retrenchment of collective responsibility? The privatisation of public pensions in Western Europe', Social Policy and Society, 2(3), 189-90.

Immergut, E.M., Anderson, K.M. and Schulze, I. (eds) (2007), Handbook of West European Pension Politics, Oxford: Oxford University Press.

Johnson, P. and Rake, K. (1998), 'Comparative social policy research in Europe', Social Policy Review, 10, 257-78.

Leisering, L. (2003), 'From redistribution to regulation: regulating private pension provision for old age as a new challenge for the welfare state in ageing societies', paper presented at the 4th International Research Conference on Social Security, Antwerp, 5-7 May, Regina Working Paper No. 3, University of Bielefeld.

Mares, I. (2001), 'Firms and the welfare state: when, why, and how does social policy matter to employers?', in P. Hall and D. Soskice (eds), Varieties of Capitalism (pp. 184-212), Oxford: Oxford University Press.

Mazey, S. (1998), 'The European Union and women's rights: from the Europeanization of national agendas to the nationalization of a European agenda?', Journal of European Public Policy, 5(1), 131-52.

Meyer, T. and Bridgen, P. (forthcoming 2008), 'Class, gender and chance: the social division of welfare and British occupational pensions', Ageing and Society.

Moffit, R.A. (1999), 'Simulating transfer programmes and labour supply', in T. Callan (ed.), Taxes, Transfers and Labour Market Responses: What can Microsimulation Tell Us?, Dublin: Economic and Social Research Institute. 
Müller, K. (1999), The Political Economy of Pension Reform in Central-Eastern Europe, Cheltenham, UK and Northampton, MA, USA: Edward Elgar.

Myles, J. and Pierson, P. (2001), 'The comparative political economy of pension reform', in P. Pierson (ed.), The New Politics of Welfare (pp. 305-33), Oxford: Oxford University Press.

OECD (2005a), Employment Outlook 2005, Paris.

OECD (2005b), Pensions at a Glance, Public Policies across OECD Countries, 2005 Edition, Paris.

OECD (2005c), Pension Markets in Focus Newsletter, June, Issue 1.

OECD (2005d), Pension Markets in Focus Newsletter, December, Issue 2.

OFS (2004), La prévoyance professionnelle en Suisse, Neuchâtel: OFS.

Pedersen, A.W. (2004), 'The privatization of retirement income? Variation and trends in the income packages of old age pensioners', Journal of European Social Policy, 14(1), 5-23.

Pierson, P. (1994), Dismantling the Welfare State?, Cambridge: Cambridge University Press.

Pierson, P. (2001), 'Post-industrial pressures on mature welfare states', in P. Pierson (ed.), The New Politics of the Welfare State (pp. 80-104), Oxford: Oxford University Press.

Quadango, J. and Hardy, M. (1996), 'Private pensions, state regulation and income security for older workers: the US auto industry', in M. Shalev (ed.), The Privatization of Social Policy? Occupational Welfare and the Welfare State in America, Scandinavia and Japan (pp. 136-58), Basingstoke: Macmillan Press.

Rake, K. (1999), 'Accumulated disadvantage? Welfare state provision and the incomes of older women and men in Britain, France and Germany', in J. Clasen (ed.), Comparative Social Policy: Concepts, Theories and Methods (pp. 22-245), Oxford: Blackwell.

Rein, M. (1996), 'Is America exceptional? The role of occupational welfare in the United States and the European Community', in M. Shalev (ed.), The Privatization of Social Policy? Occupational Welfare and the Welfare State in America, Scandinavia and Japan (pp. 27-43), Basingstoke: Macmillan Press.

Rein, M. and Schmähl, W. (eds) (2004), Rethinking the Welfare State: The Political Economy of Pension Reform, Cheltenham, UK and Northampton, MA, USA: Edward Elgar.

Rein, M. and Wadensjö, U. (1997), 'The emerging role of enterprise in social policy', in M. Rein and E. Wadensjo (eds), Enterprise and the Welfare State, Cheltenham, UK and Lyme, USA: Edward Elgar.

Ross, D. and Wills, L. (2002), 'The shift from defined benefit to defined contribution retirement plans and the provision of retirement savings', Pensions Institute Discussion Paper PI-0210, London: Pensions Institute.

Sass, S. (1997), The Promise of Private Pensions: The First Hundred Years, Cambridge, MA: Harvard University Press.

Schulze, I. and Jochem, S. (2007), 'Germany: beyond policy gridlock', in E.M. Immergut, K.M. Anderson and I. Schulze (eds), Handbook of West European Pension Politics (pp. 660-711), Oxford: Oxford University Press.

Shalev, M. (ed.) (1996), The Privatization of Social Policy? Occupational Welfare in America, Scandinavia and Japan, Basingstoke: Macmillan.

Sinfield, A. (2000), 'Tax benefits in non-state pensions', European Journal of Social Security, 2(2), 137-68. 
Social Protection Committee (2006), 'Current and prospective theoretical pension replacement rates', Report by the Indicators Sub-Group (ISG) of the (SPC), 19 May 2006, http://ec.europa.eu/employment_social/social_protection/docs/ isg_repl_rates_en.pdf, accessed 17 January 2007.

Stroinski, K. (1998), 'Poland: the reform of the pension system', Agenda, March, 29-33, http://agenda.anu.edu.au/, accessed 20 August 2006.

Swiss Federal Statistical Office (2005a), Employment Statistics, Neuchâtel: SFSO.

Swiss Federal Statistical Office (2005b), Swiss Labour Force Survey 2005, Neuchâtel: SFSO.

Titmuss, R. (1958), Essays on the Welfare State, London: Allen \& Unwin.

Townsend, P. (1979), Poverty in the United Kingdom: A Survey of Household Resources and Standards of Living, Harmondsworth: Penguin.

van Gunsteren, H. and Rein, R. (1985), 'The dialectic of public and private pensions', Journal of Social Policy, 14(2), 129-49.

van Riel, B., Hemerijck, A. and Visser, J. (2003), 'Is there a Dutch way to pension reform?', in G. Clark and N. Whiteside (eds), Pension Security in the 21 st Century (pp. 64-91), Oxford: Oxford University Press.

Whiteside, N. (2003), 'Historical perspectives and the politics of pension reform', in G. Clark and N. Whiteside (eds), Pension Security in the 21st Century (pp. 21-43), Oxford: Oxford University Press.

Whiteside, N. (2006), 'Adapting private pensions to public purposes: historical perspectives on the politics of reform', Journal of European Social Policy, 16(1), $43-54$.

World Bank (1994), Averting the Old Age Crisis, Oxford: Oxford University Press.

Zaidi, A., Marin, B. and Fuchs, M. (2006), Pension Policy in EU 25 and its Possible Impact on Elderly Poverty, Vienna: European Centre for Social Welfare Policy and Research. 


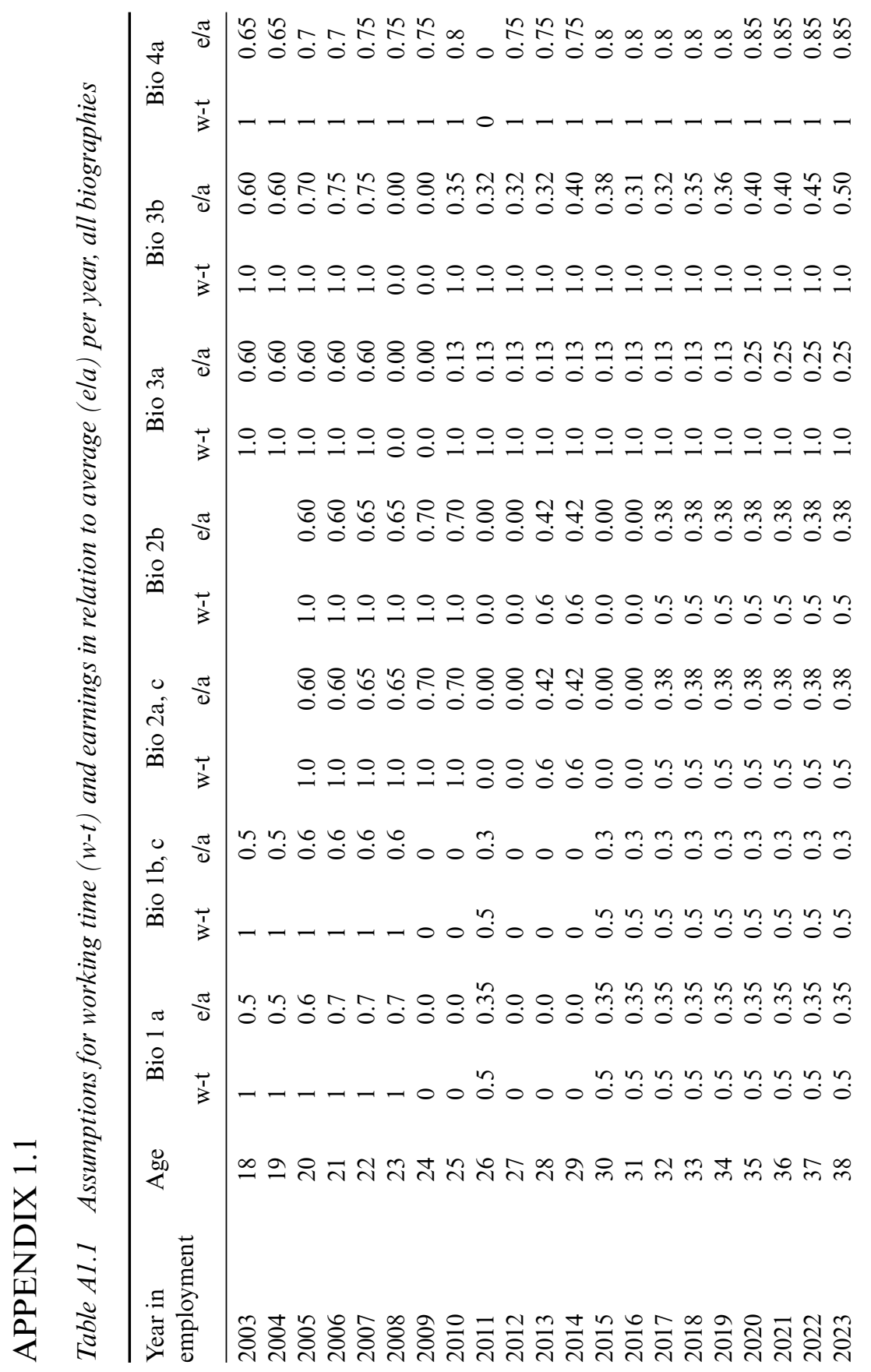




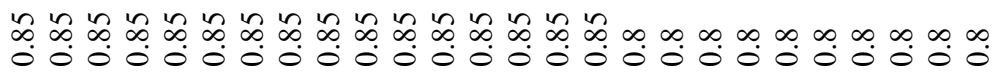

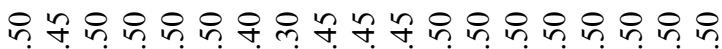

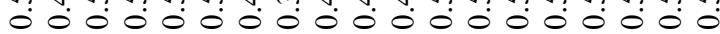

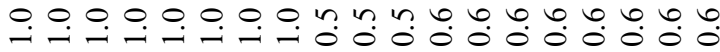

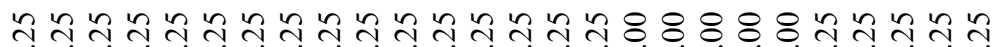

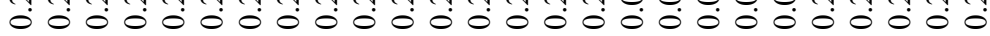

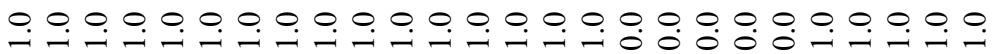

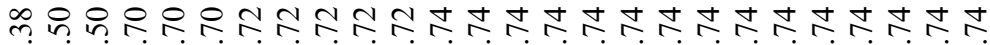
00000000000000000000000000

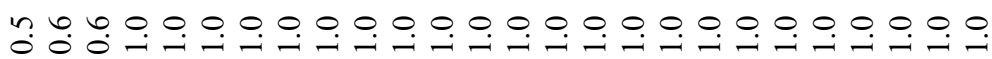

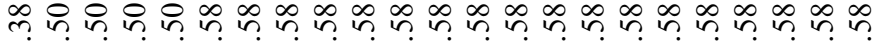
00000000000000000000000

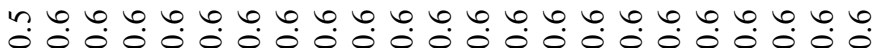
m

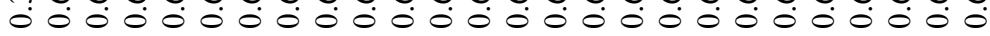

$\dddot{0}$

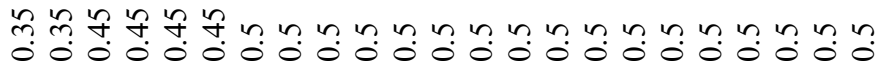

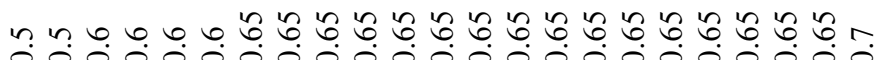

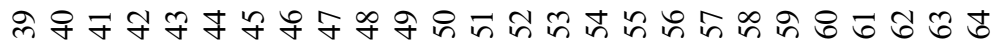

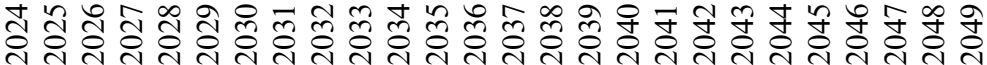




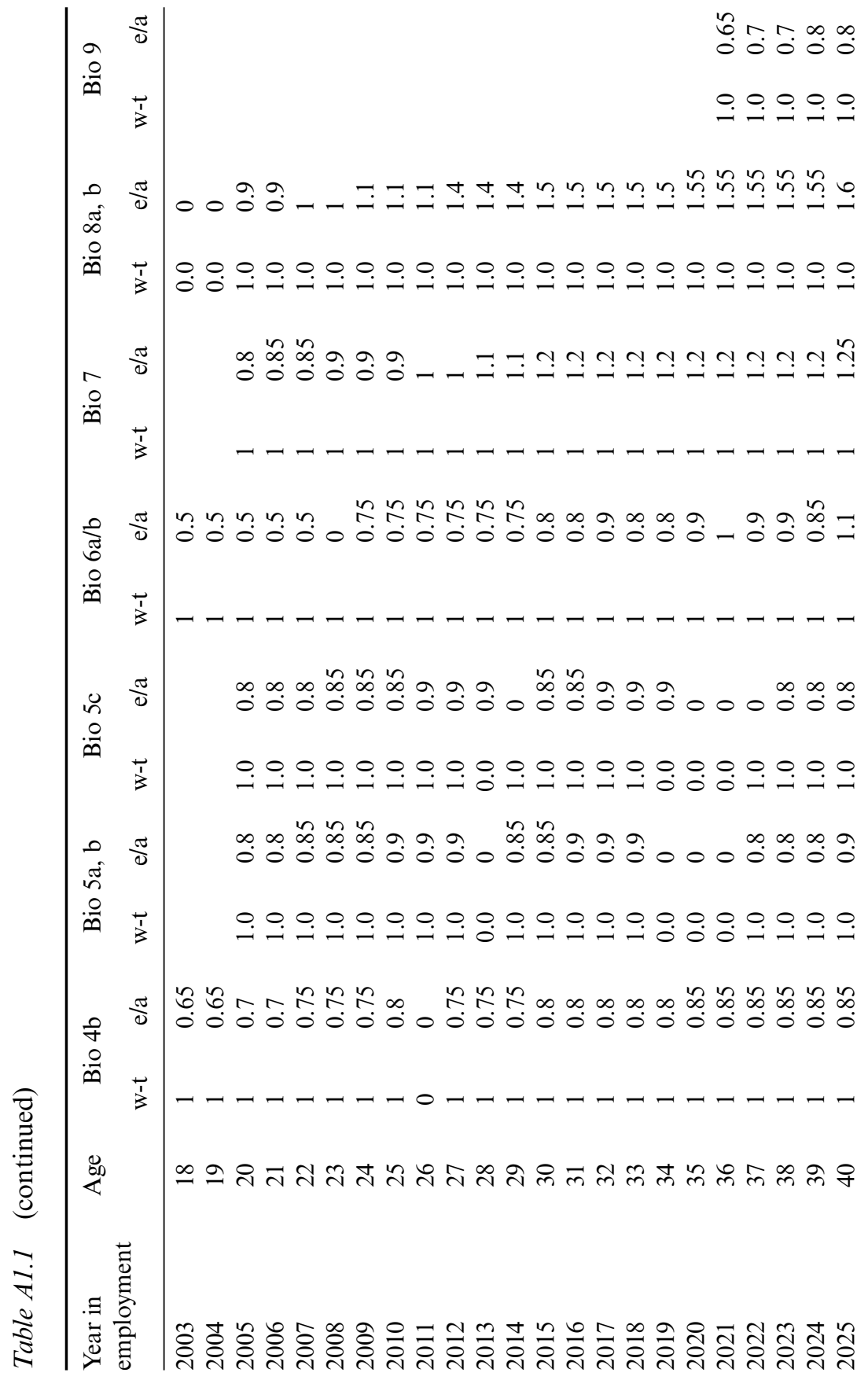




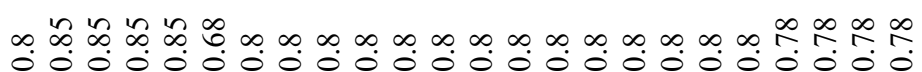

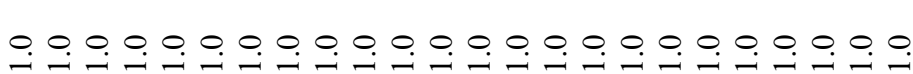

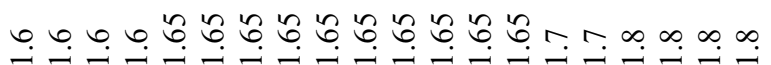

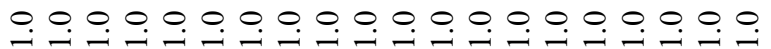

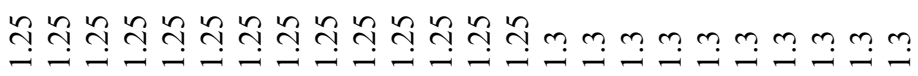

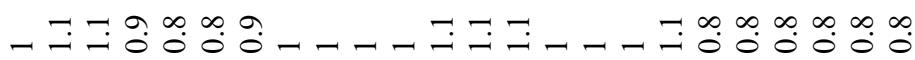

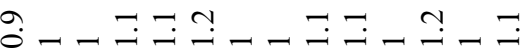

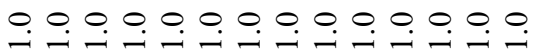

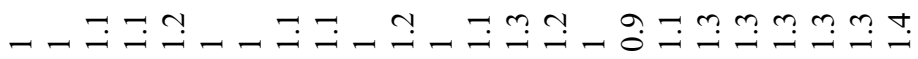

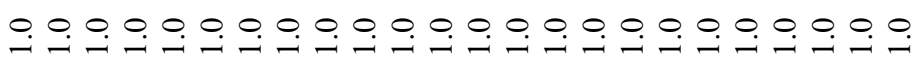

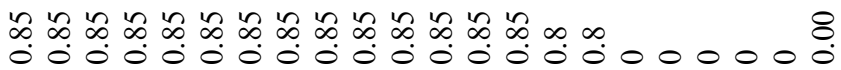

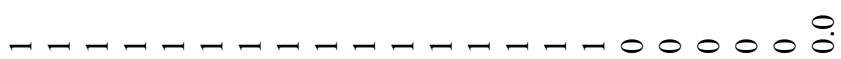

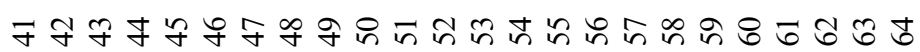

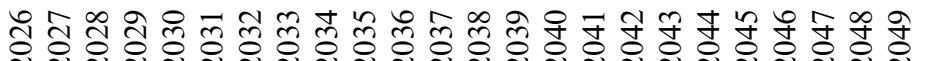




\section{APPENDIX 1.2}

Table A1.2 Details of assumptions used in the simulations in all countries

\begin{tabular}{|c|c|c|}
\hline Assumption & Details & Comments \\
\hline General & & $\begin{array}{l}\text { In general, we have based our } \\
\text { assumptions on those used by policy- } \\
\text { makers in Europe. In some cases, for } \\
\text { reasons explained below we have } \\
\text { adopted slightly more optimistic } \\
\text { assumptions, but we have not adopted } \\
\text { any assumptions that are more } \\
\text { pessimistic. }\end{array}$ \\
\hline \multicolumn{3}{|l|}{ Economic data } \\
\hline Average wages & $\begin{array}{l}\text { Annual Gross } \\
\text { Earnings in Industry } \\
\text { and Services: } \\
\text { Eurostat data } \\
\text { for } 2003 \text {. http://epp. } \\
\text { eurostat.ec.europa.eu }\end{array}$ & $\begin{array}{l}\text { Gross earnings are remuneration (wages } \\
\text { and salaries) in cash paid directly to the } \\
\text { employee, before any income tax and } \\
\text { social security contributions paid by the } \\
\text { employee. Data is presented for full- } \\
\text { time employees in industry and services. } \\
\text { We used average rather than median } \\
\text { earnings because median earnings were } \\
\text { not available for all countries. }\end{array}$ \\
\hline Inflation & $\begin{array}{l}1.9 \% \text { - based on EU } \\
\text { assumptions (www. } \\
\text { ecb.int/mopo/html/ } \\
\text { index.en.html). }\end{array}$ & $\begin{array}{l}1.9 \% \text { is the European Central Bank's } \\
\text { inflation target. }\end{array}$ \\
\hline Gross earnings & $\begin{array}{l}\text { Annual rise } 2 \% \\
\text { above inflation. }\end{array}$ & $\begin{array}{l}\text { Gross disposable income rose in the } \\
\text { Eurozone by an average of } 3.9 \% \text { in } \\
\text { the five years up to } 2003 \text { (European } \\
\text { Central Bank 2004). }\end{array}$ \\
\hline Exchange rate & $\begin{array}{l}\text { As of } 1.1 .2003 . \\
\text { For } \mathrm{CH}: 1 \mathrm{CHF}= \\
0.68951 € ; \mathrm{UK}: 1 \\
\mathrm{GBP}=1.53 €\end{array}$ & \\
\hline \multicolumn{3}{|c|}{ Pension system assumptions } \\
\hline $\begin{array}{l}\text { State pension } \\
\text { system }\end{array}$ & $\begin{array}{l}\text { Rules and stipulations } \\
\text { of public pension } \\
\text { regime as valid in } \\
\text { 2003. See country } \\
\text { chapters for details. }\end{array}$ & \\
\hline $\begin{array}{l}\text { State pension } \\
\text { age }\end{array}$ & $\begin{array}{l}\text { In Poland the state } \\
\text { pension age for }\end{array}$ & \\
\hline
\end{tabular}


Table A1.2 (continued)

\begin{tabular}{|c|c|c|}
\hline Assumption & Details & Comments \\
\hline & $\begin{array}{l}\text { women is } 60 \text {. To } \\
\text { allow comparison, } \\
\text { the pensions of } \\
\text { Polish women on } \\
\text { retirement have been } \\
\text { projected forward to } \\
65 \text { on the basis of } \\
\text { the price index. }\end{array}$ & \\
\hline $\begin{array}{l}\text { Early } \\
\text { retirement }\end{array}$ & $\begin{array}{l}\text { In circumstances } \\
\text { where a biography } \\
\text { retires early (ie bios } \\
2 \mathrm{a}, 2 \mathrm{c}, 4 \mathrm{~b}, 8 \mathrm{a} \text { and } 8 \mathrm{~b} \text { ) } \\
\text { any pension they } \\
\text { receive on retirement } \\
\text { has been projected } \\
\text { forward to } 65 \text { on the } \\
\text { basis of the price } \\
\text { index. }\end{array}$ & \\
\hline $\begin{array}{l}\text { Occupational } \\
\text { pension } \\
\text { scheme } \\
\text { stipulations }\end{array}$ & $\begin{array}{l}\text { Rules and stipulations } \\
\text { of selected } \\
\text { occupation schemes } \\
\text { as valid in 2003. See } \\
\text { country chapters for } \\
\text { details. }\end{array}$ & \\
\hline $\operatorname{Tax}$ & $\begin{array}{l}\text { Our simulations } \\
\text { exclude tax and } \\
\text { social insurance } \\
\text { contributions or } \\
\text { benefits. We use gross } \\
\text { earnings to calculate } \\
\text { pension entitlement } \\
\text { and our pension } \\
\text { outcomes are gross } \\
\text { figures. }\end{array}$ & $\begin{array}{l}\text { Tax and benefits are excluded as a } \\
\text { means of simplifying an already } \\
\text { complex comparative methodology. } \\
\text { Recent research undertaken by the } \\
\text { OECD suggests that the effect of tax on } \\
\text { pension outcomes is similar across the } \\
\text { six countries included in this study. It } \\
\text { concluded that 'the differential between } \\
\text { gross and net replacement rates for low } \\
\text { earners is } 17 \% \text { on average', with little } \\
\text { significant variation between countries } \\
\text { OECD ( } 2005 \mathrm{a}, \text { p. } 17) \text {. }\end{array}$ \\
\hline
\end{tabular}

Thresholds

Social

assistance

The basic social

Social assistance was not generally used assistance benefit for older people, for comparative analysis because of significant variations in social assistance 
Table A1.2 (continued)

\begin{tabular}{|c|c|c|}
\hline Assumption & Details & Comments \\
\hline & $\begin{array}{l}\text { excluding allowances } \\
\text { for specific items of } \\
\text { expenditure, such as } \\
\text { housing unless these } \\
\text { are an inherent part } \\
\text { of the basic benefit } \\
\text { (eg Germany). Given } \\
\text { that some individual } \\
\text { biographies are } \\
\text { married at retirement, } \\
\text { the social assistance } \\
\text { threshold for them is } \\
\text { half of couple's social } \\
\text { assistance rate in } 2050 . \\
\text { The threshold for } \\
\text { single individuals is } \\
\text { the single person's rate. }\end{array}$ & $\begin{array}{l}\text { rates between countries in relation to } \\
\text { average income but it is nevertheless } \\
\text { important to assess whether each } \\
\text { country's pension system succeeds in } \\
\text { providing benefits above the nationally } \\
\text { determined minimum standard. }\end{array}$ \\
\hline Social exclusion & $\begin{array}{l}\text { Social inclusion } \\
\text { threshold: } 40 \% \text { of } \\
\text { average wages; } \\
\text { comfortable social } \\
\text { inclusion threshold: } \\
50 \% \text { of average wages. }\end{array}$ & $\begin{array}{l}\text { Median income data from one dataset } \\
\text { was not available for all countries, thus } \\
\text { we could not use the standard EU } \\
\text { threshold for social exclusion - } 60 \text { per } \\
\text { cent of median income, but used } \\
\text { average wage data instead. For social } \\
\text { inclusion we chose a } 40 \% \text { average wage } \\
\text { threshold rather than the more standard } \\
50 \% \text { threshold because of concerns that } \\
\text { the latter was significantly higher than } \\
60 \% \text { median figures in some of our } \\
\text { countries. }\end{array}$ \\
\hline
\end{tabular}

Savings

Period of saving All years of employed working life.

This is an optimistic assumption. The earliest age at which Britain's recent Pensions Commission assumed saving started was 25 . In savings calculations undertaken by the British Department of Work and Pensions the youngest age included was 20 (DWP 2002: 35).

Scale of saving Same proportion of This is a common assumption made in earnings during undertaking savings calculations (see every year of saving. Pensions Commission 2004: 150-156). 
Table A1.2 (continued)

\begin{tabular}{|c|c|c|}
\hline Assumption & Details & Comments \\
\hline Rate of return & $\begin{array}{l}\text { For all defined } \\
\text { contribution } \\
\text { occupational } \\
\text { pensions and savings } \\
\text { calculations we have } \\
\text { assumed a real gross } \\
\text { rate of return of } 6 \\
\text { per cent. }\end{array}$ & $\begin{array}{l}\text { This is an optimistic assumption which } \\
\text { was chosen to assess the potential of } \\
\text { personal saving in the best possible } \\
\text { circumstances. In simulating pension } \\
\text { outcomes up to } 2050 \text {, the UK } \\
\text { government was more cautious: its } \\
\text { assumption for annual rates of return } \\
\text { was that they would average } 2 \% \text { above } \\
\text { average wage growth (DWP } 2002 \text { ), ie } \\
4 \text { per cent in real terms and } 5.9 \text { per cent } \\
\text { in nominal terms. Our assumption is } \\
\text { more in line with data on stock market } \\
\text { rates of return in the best-performing } \\
\text { countries over the last } 100 \text { years (see } \\
\text { Dimson et al. 2002). }\end{array}$ \\
\hline Annuity rate & $\begin{array}{l}5 \% \text { annuity rate on } \\
\text { retirement. }\end{array}$ & $\begin{array}{l}\text { Annuity rate is in line with situation in } \\
2004 \text { (sharingpensions.co.uk, 2004). We } \\
\text { have used the same annuity rate for } \\
\text { male and female biographies because in } \\
\text { some of our countries (Germany and } \\
\text { Switzerland) rates are not by law } \\
\text { differentiated by gender. }\end{array}$ \\
\hline
\end{tabular}


Paul Bridgen and Traute Meyer - 9781847208804 Downloaded from PubFactory at 04/25/2023 11:59:20PM via free access 